$10.2478 /$ cris-2014-0003

\title{
REPORT ON THE FINANCIAL EVALUATION: MCDONALD'S CORPORATION AND YUM! BRANDS
}

TAMARA AYRAPETOVA

The aim of this paper is to perform financial analysis by using financial ratios and to comment, evaluate, and understand the origins of the results by using the comparison of two companies chosen as a case study.

The McDonald's Corporation is the largest fast food restaurant in the world. McDonald's Corporation statistics base it in over 119 countries and it serves more than 68 million customers daily. The company's revenues are coming not only from its primary products like hamburgers, cheeseburgers, etc., but also from rent, royalties, and fees paid by the franchisees. This report will look at the financial statements of the McDonald's Corporation over the past 3 years starting from 2010 through 2012. The author of the paper will apply financial ratios to analyze company's position and to identify patterns and trends. She will then compare the results of the analysis with one of the biggest competitors of McDonald's - Yum! Brands Inc. and the industrial averages. Yum! Brands Inc. is a US based corporation. It includes famous brands like KFC and Pizza Hut in their chain. Currently Yum! Brands are the largest competitors McDonald's has in the fast-food industry. To compare the two companies financial statements will be taken from Yahoo Finance (2013). 
To start this paper, the author will first give graphical comparisons of several financial factors, which determine the company's performance. The author will focus on total revenue, gross and net incomes of the companies to understand if there is a tendency in the industry. The analysis consists of data from over 5 years.

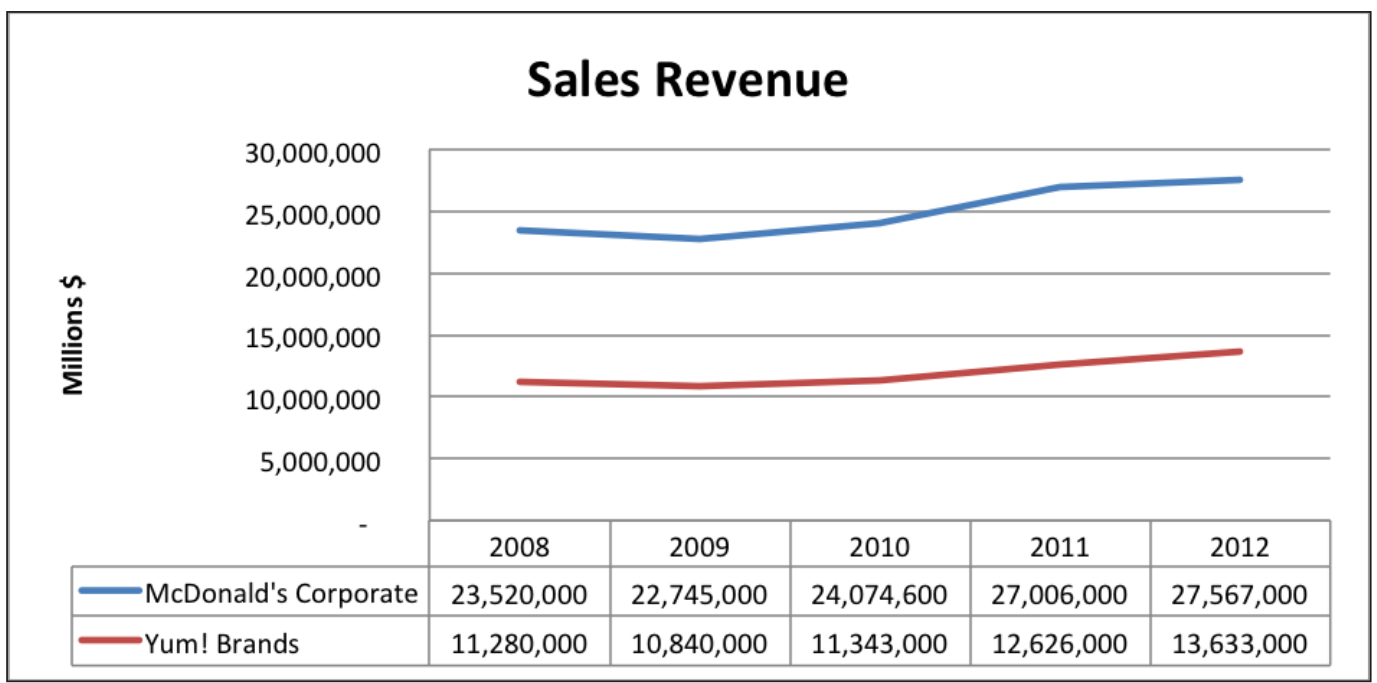

Figure 1: Sales Revenue Comparison McDonald's vs. Yum! Brands.

As one can see from the above graph, even though Yum! Brands are the second biggest chain, the total revenues are still considerably lower in comparison to the $M c D$ Donald's revenues over the same period of time. We can see that there are trends in the movement as both of the companies experienced decline in revenues during the years 2009-2010. One of the main reasons this could be is the crisis the US was experiencing during that time. Looking at the gross profit and net profit we can also see the same tendency the lines do show a decrease in profits over 2009-2010 and an increase over 2011-2012. One can also see that McDonald's has experienced much more sufficient increase in income both gross and net in 2011 than Yum! Brands.

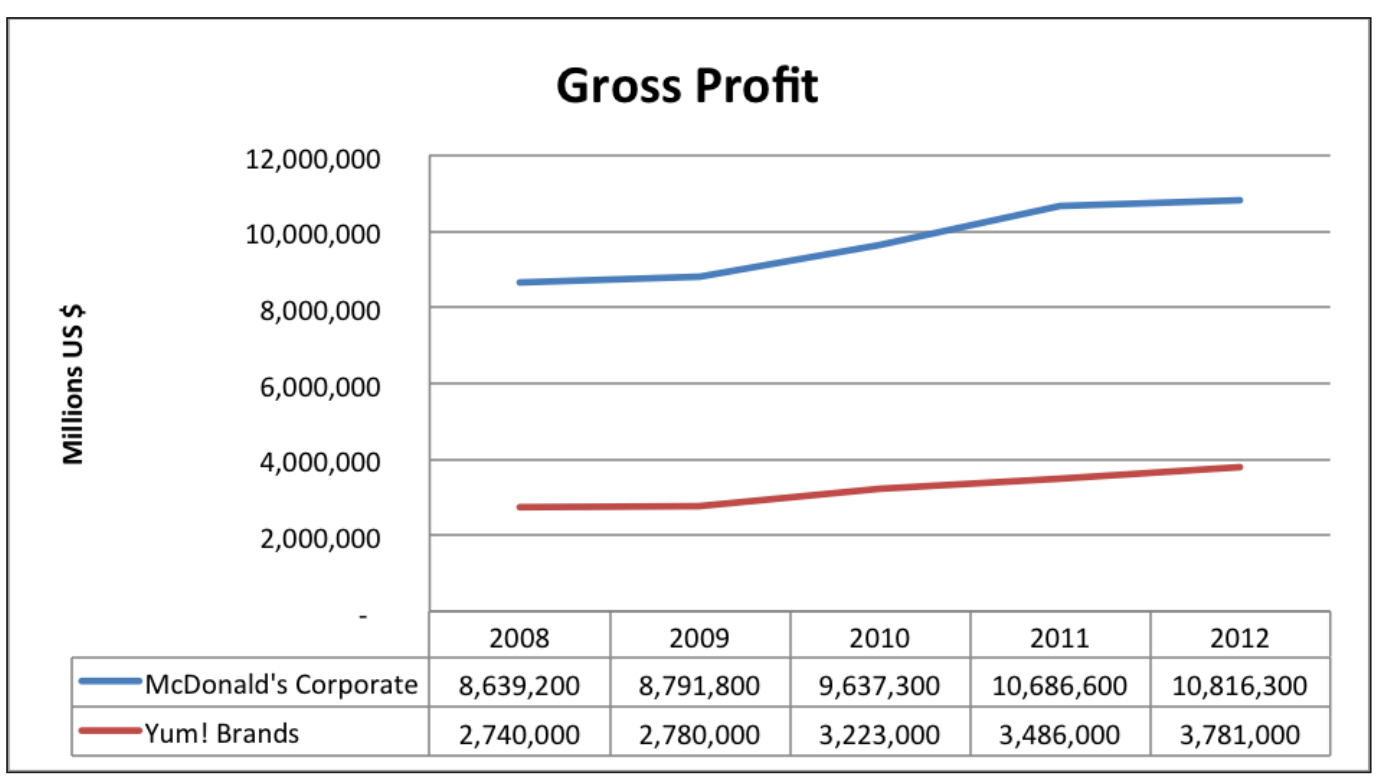




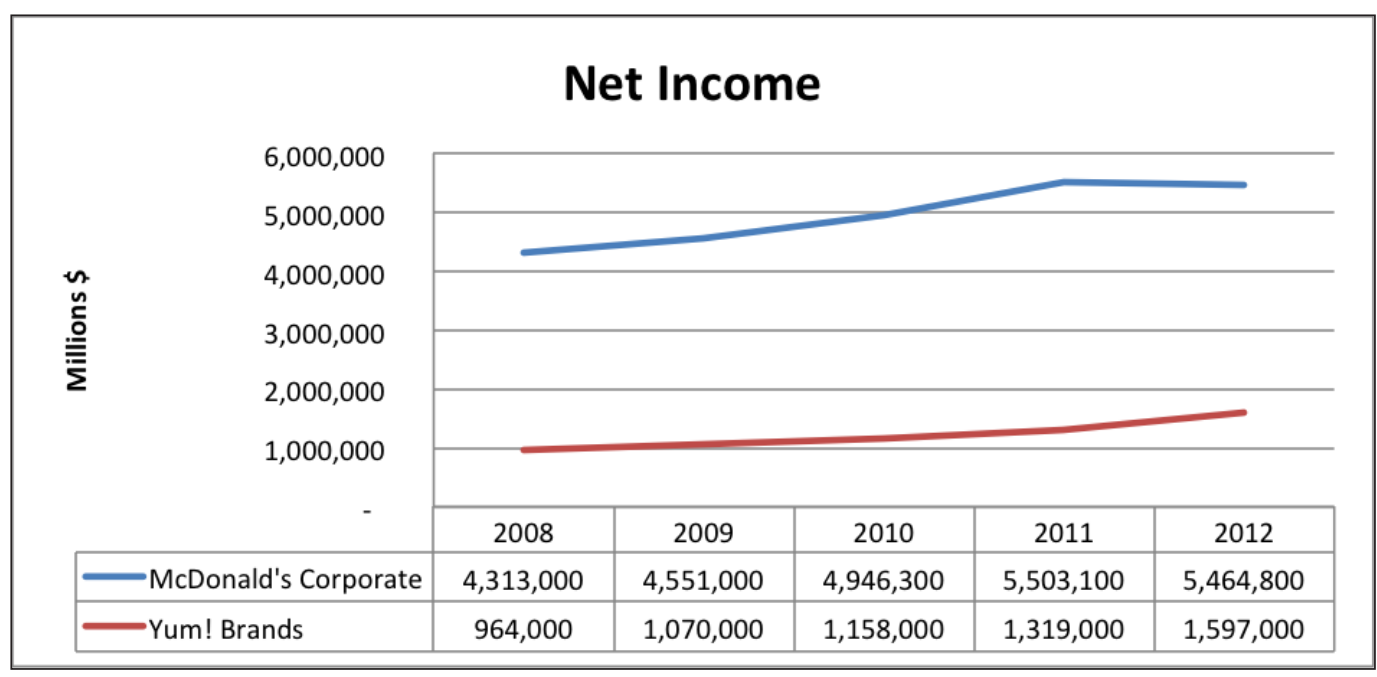

Figure 3: Net Income Comparison McDonald's vs. Yum! Brands.

\section{FINANCIAL ANALYSIS}

In this part of the paper we will look at the financial ratios and apply them to both of the companies. The author will firstly define the formulas used to calculate the ratios and then will comment on the results.

\subsection{LIQUIDITY ANALYSIS}

Liquidity ratios allow us to measure the ability of the company to meet its short-term obligations. Mainly they highlight if the company can pay off its liabilities on the due date. In this paper we will use Current Assets and Acid Test to see if McDonald's and Yum! Brands have THE necessary liquidity. Generally, the higher are the result of the ratios, the better the financial health of the company is. The desired minimum in this case would be value of 1 .

$$
\begin{gathered}
\text { Current Assets }=\frac{\text { Current Assets }}{\text { Current Liabilities }} \\
\text { Acid test }=\frac{\text { Current Asset }- \text { Stock(Inventory) }}{\text { Current Liabilities }}
\end{gathered}
$$

The results of those ratios one can find below:

TABLE 1 - MCDONALD'S CORPORATION

\begin{tabular}{|l|r|r|r|}
\hline & 2010 & 2011 & 2012 \\
\hline Current Assets & 4368500 & 4403000 & 4922100 \\
\hline Current Liabilities & 2924700 & 3509200 & 3403100 \\
\hline Current Asset Ratio & 1,49 & 1,25 & 1,446357733 \\
\hline
\end{tabular}

TABLE 2 - YUM! BRANDS

\begin{tabular}{|l|r|r|r|}
\hline & $\mathbf{2 0 1 0}$ & $\mathbf{2 0 1 1}$ & $\mathbf{2 0 1 2}$ \\
\hline Current Assets & 2313000 & 2321000 & 1909000 \\
\hline Current Liabilities & 2448000 & 2450000 & 2188000 \\
\hline Current Asset Ratio & 0,94 & 0,95 & 0,872486289 \\
\hline
\end{tabular}


Current asset ratios shows the extent to which company is able to meet its short-term obligations, and as we can see, McDonald's has higher results than Yum! Brands. For all 3 years, Yum! Brands shows results lower than 1, which shows that they might have issues to pay their obligations. The reason why the results are so low is because Yum! Brands' current liabilities are higher than the assets the company holds (see Figure 4).

Looking at the Acid Test we can see similar trend:

TABLE 3 - MCDONALD'S CORPORATION

\begin{tabular}{|l|r|r|r|}
\hline & $\mathbf{2 0 1 0}$ & $\mathbf{2 0 1 1}$ & $\mathbf{2 0 1 2}$ \\
\hline Current Assets & 4368500 & 4403000 & 4922100 \\
\hline Intentory & 109000 & 116800 & 121700 \\
\hline Current Liabilities & 2924700 & 3509200 & 3403100 \\
\hline Acid Ratio & 1,46 & 1,22 & 1,41 \\
\hline
\end{tabular}

TABLE 4 - YUM! BRANDS

\begin{tabular}{|l|r|r|r|}
\hline & $\mathbf{2 0 1 0}$ & $\mathbf{2 0 1 1}$ & $\mathbf{2 0 1 2}$ \\
\hline Current Assets & 2313000 & 2321000 & 1909000 \\
\hline Intentory & 189000 & 273000 & 313000 \\
\hline Current Liabilities & 2448000 & 2450000 & 2188000 \\
\hline Current Asset Ratio & 0,87 & 0,84 & 0,73 \\
\hline
\end{tabular}

McDonald's has values over 1, which shows that the company is in a stable position whereas Yum! Brands are still showing results lower than 1 , which shows that the company can have liquidity issues as large part of its current assets is actually inventory/stock which cannot be used to meet the obligations.

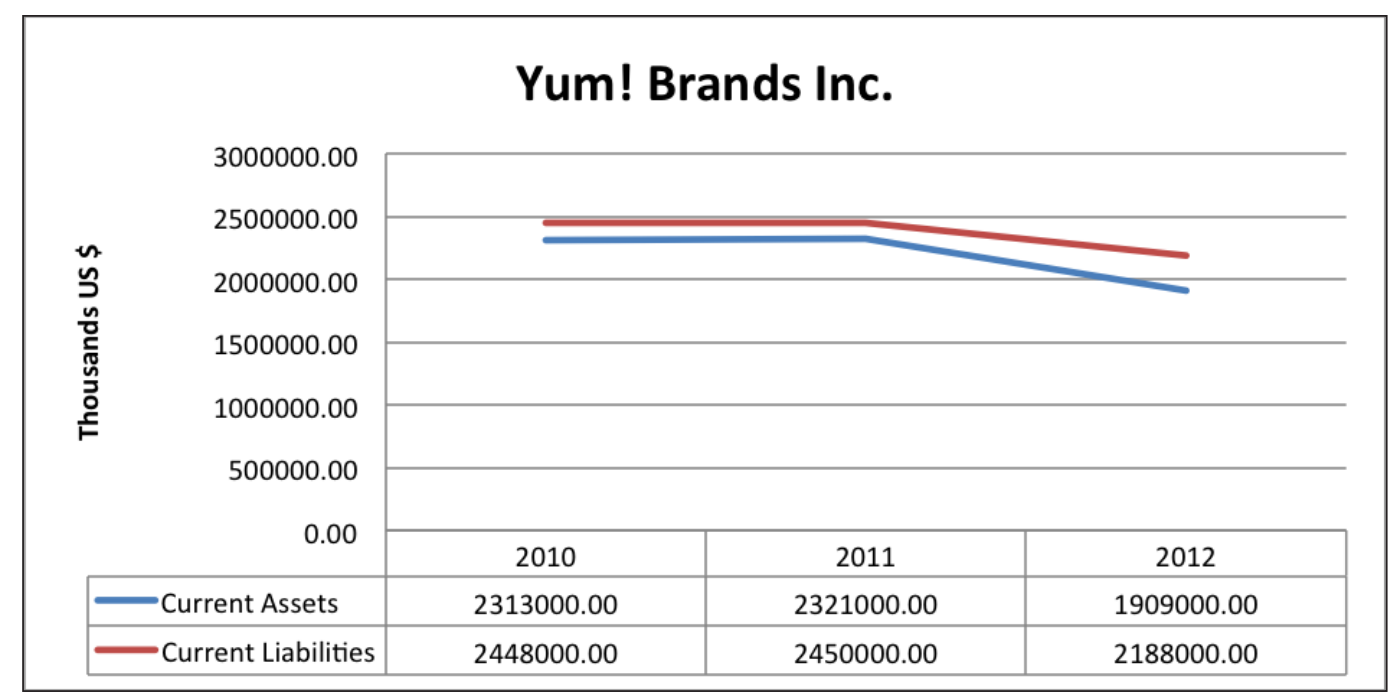

Figure 4: Current Assets to Current Liabilities Yum! Brands. 
This leads us to another factor to consider when looking at liquidity, which is working capital (WC). Working capital shows us operational liquidity. The higher is WC, the lower is the chance of cash flow problems, and the more liabilities are covered by the currently owned assets. The formula for WC is:

\section{Working Capital $=$ Current Assets - Current Liabilities}

One can find the results for both McDonald's and Yum! Brands below:

TABLE 5 - MCDONALD'S CORPORATION

\begin{tabular}{|l|r|r|r|}
\hline & $\mathbf{2 0 1 0}$ & $\mathbf{2 0 1 1}$ & $\mathbf{2 0 1 2}$ \\
\hline Current Assets & 4368500 & 4403000 & 4922100 \\
\hline Current Liabilities & 2924700 & 3509200 & 3403100 \\
\hline Working Capital & 1443800 & 893800 & 1519000 \\
\hline
\end{tabular}

TABLE 6 - YUM! BRANDS

\begin{tabular}{|l|r|r|r|}
\hline & $\mathbf{2 0 1 0}$ & $\mathbf{2 0 1 1}$ & $\mathbf{2 0 1 2}$ \\
\hline Current Assets & 2313000 & 2321000 & 1909000 \\
\hline Current Liabilities & 2448000 & 2450000 & 2188000 \\
\hline Working Capital & -135000 & -129000 & -279000 \\
\hline
\end{tabular}

If we look at the results for WC, one can see that Yum! Brands experience WC problems. These results go together with acid and current asset ratios. The liabilities Yum! Brands has dramatically exceeded their assets, which can cause issues for them to pay their short-term liabilities. McDonald's is doing pretty good, even though the results are not ideal in terms of coverage (not 2:1) and are showing fluctuations, for example, in the year 2011.

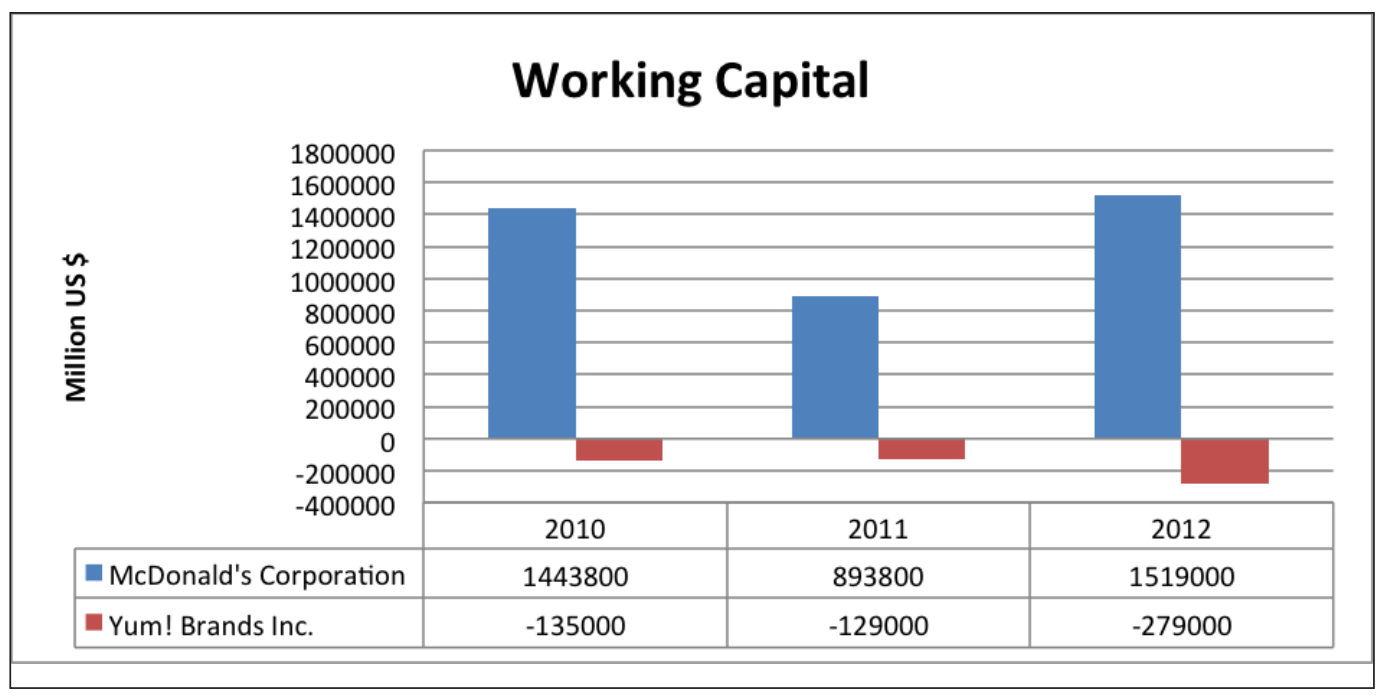

Figure 5: Working Capital McDonald's vs. Yum! Brands. 


\subsection{PROFITABILITY ANALYSIS}

Profitability ratios help to measure a company's ability to generate earnings, profits, and cash flows by comparing the budget invested and the cash results of sales. In this paper we will use the Return on Capital Employed (ROCE) ratio to compare the cash earned with the cash invested. Gross Profit Margin is used to see the percentage by which profits exceed production costs and Net Profit Margin to see the amount of profit made after expenses and tax per sales dollar.

$$
\text { ROCE }=\frac{\text { Earnings Before Interest and Tax }}{\text { Capital Employed }} * 100 \text { or } \mathbf{R O C E}=\frac{\text { Profit Margin }}{\text { Asset Turnover }}
$$

Capital Employed $=$ Total Assets - Current Liabilities

$$
\begin{gathered}
\text { Gross Profit Margin }=\frac{\text { Gross Profit }}{\text { Total Revenue }} * 100 \\
\text { Net Profit Margin }=\frac{\text { Net Profit }}{\text { Total Revenue }} * 100
\end{gathered}
$$

The results for both of the companies are represented below:

\begin{tabular}{|c|c|c|c|}
\hline Capital Employed & 2010 & 2011 & 2012 \\
\hline Total Assets & 31975200 & 32989900 & 35386500 \\
\hline Current Liabilities & 2924700 & 3509200 & 3403100 \\
\hline CE & 29050500 & 29480700 & 31983400 \\
\hline
\end{tabular}

TABLE 7 - PROFITABILITY RATIOS - MCDONALD'S CORPORATION

\begin{tabular}{|l|r|r|r|}
\hline & $\mathbf{2 0 1 0}$ & $\mathbf{2 0 1 1}$ & $\mathbf{2 0 1 2}$ \\
\hline Earnings Before Interest and Taxes & 8595600 & 8505000 & 8595600 \\
\hline Capital Employed & 29050500 & 29480700 & 31983400 \\
\hline ROCE & $\mathbf{3 0 \%}$ & $\mathbf{2 9 \%}$ & $\mathbf{2 7 \%}$ \\
\hline
\end{tabular}

\begin{tabular}{|l|r|r|r|}
\hline Asset Turnover & $\mathbf{2 0 1 0}$ & $\mathbf{2 0 1 1}$ & $\mathbf{2 0 1 2}$ \\
\hline Sales Revenue/Total Revenue & 24074600 & 27006000 & 27567000 \\
\hline Total Stockholder Equity & 14634200 & 11737000 & 12489600 \\
\hline AT & $\mathbf{1 , 6 5}$ & $\mathbf{2 , 3 0}$ & $\mathbf{2 , 2 1}$ \\
\hline
\end{tabular}

\begin{tabular}{|l|r|r|r|}
\hline ROCE & $\mathbf{2 0 1 0}$ & $\mathbf{2 0 1 1}$ & $\mathbf{2 0 1 2}$ \\
\hline Profit Margin & 0,3570402 & 0,314930016 & 0,311807596 \\
\hline Asset Turnover & 0,83 & 0,92 & 0,86 \\
\hline PM(\%) * AT & $\mathbf{3 0 \%}$ & $\mathbf{2 9 \%}$ & $\mathbf{2 7 \%}$ \\
\hline
\end{tabular}

\begin{tabular}{|l|r|r|r|}
\hline & $\mathbf{2 0 1 0}$ & $\mathbf{2 0 1 1}$ & $\mathbf{2 0 1 2}$ \\
\hline Gross Profit & 9637300 & 10686600 & 10816300 \\
\hline Net Income & 4946300 & 5503100 & 5464800 \\
\hline Sales Revenue/Total Revenue & 24074600 & 27006000 & 27567000 \\
\hline Gross Profit Margin & $\mathbf{4 0 \%}$ & $\mathbf{4 0 \%}$ & $\mathbf{3 9 \%}$ \\
\hline Net Profit Margin & $\mathbf{2 1 \%}$ & $\mathbf{2 0 \%}$ & $\mathbf{2 0 \%}$ \\
\hline
\end{tabular}


TABLE 8 - PROFITABILITY RATIOS - YUM! BRANDS

\begin{tabular}{|l|r|r|r|}
\hline & $\mathbf{2 0 1 0}$ & $\mathbf{2 0 1 1}$ & $\mathbf{2 0 1 2}$ \\
\hline Earnings Before Interest and Taxes & 1594000 & 1659000 & 2145000 \\
\hline Capital Employed & 5868000 & 6384000 & 6823000 \\
\hline ROCE & $\mathbf{2 7 \%}$ & $\mathbf{2 6 \%}$ & $\mathbf{3 1 \%}$ \\
\hline
\end{tabular}

\begin{tabular}{|l|r|r|r|}
\hline Capital Employed & $\mathbf{2 0 1 0}$ & $\mathbf{2 0 1 1}$ & $\mathbf{2 0 1 2}$ \\
\hline Total Assets & 8316000 & 8834000 & 9011000 \\
\hline Current Liabilities & 2448000 & 2450000 & 2188000 \\
\hline CE & $\mathbf{5 8 6 8 0 0 0}$ & $\mathbf{6 3 8 4 0 0 0}$ & $\mathbf{6 8 2 3 \mathbf { 0 0 0 }}$ \\
\hline
\end{tabular}

\begin{tabular}{|l|r|r|r|}
\hline Asset Turnover & $\mathbf{2 0 1 0}$ & $\mathbf{2 0 1 1}$ & $\mathbf{2 0 1 2}$ \\
\hline Sales Revenue/Total Revenue & 11343000 & 12626000 & 13633000 \\
\hline Total Stockholder Equity & 1576000 & 1823000 & 2154000 \\
\hline AT & $\mathbf{7 , 2 0}$ & $\mathbf{6 , 9 3}$ & $\mathbf{6 , 3 3}$ \\
\hline
\end{tabular}

\begin{tabular}{|l|r|r|r|}
\hline ROCE & $\mathbf{2 0 1 0}$ & $\mathbf{2 0 1 1}$ & $\mathbf{2 0 1 2}$ \\
\hline Profit Margin & 0,140527197 & 0,131395533 & 0,15733881 \\
\hline Asset Turnover & 1,93 & 1,98 & 2,00 \\
\hline PM(\%) * AT & $\mathbf{2 7 \%}$ & $\mathbf{2 6 \%}$ & $\mathbf{3 1 \%}$ \\
\hline
\end{tabular}

\begin{tabular}{|l|r|r|r|}
\hline & $\mathbf{2 0 1 0}$ & $\mathbf{2 0 1 1}$ & $\mathbf{2 0 1 2}$ \\
\hline Gross Profit & 3223000 & 3486000 & 3781000 \\
\hline Net Income & 1158000 & 1319000 & 1597000 \\
\hline Sales Revenue/Total Revenue & 11343000 & 12626000 & 13633000 \\
\hline Gross Profit Margin & $\mathbf{2 8 \%}$ & $\mathbf{2 8 \%}$ & $\mathbf{2 8 \%}$ \\
\hline Net Profit Margin & $\mathbf{1 0} \%$ & $\mathbf{1 0 \%}$ & $\mathbf{1 2 \%}$ \\
\hline
\end{tabular}

From above tables one can see that McDonald's generally has high ROCE, Gross and Net Profit Margins over the 3 years. However, in the year 2012 Yum! Brands have higher ROCE than McDonald's (see Figure 6) as their earnings before tax and interest increased, whereas McDonald's capital employed increased dramatically and the actual return stayed nearly the same as in 2011 which caused decline.

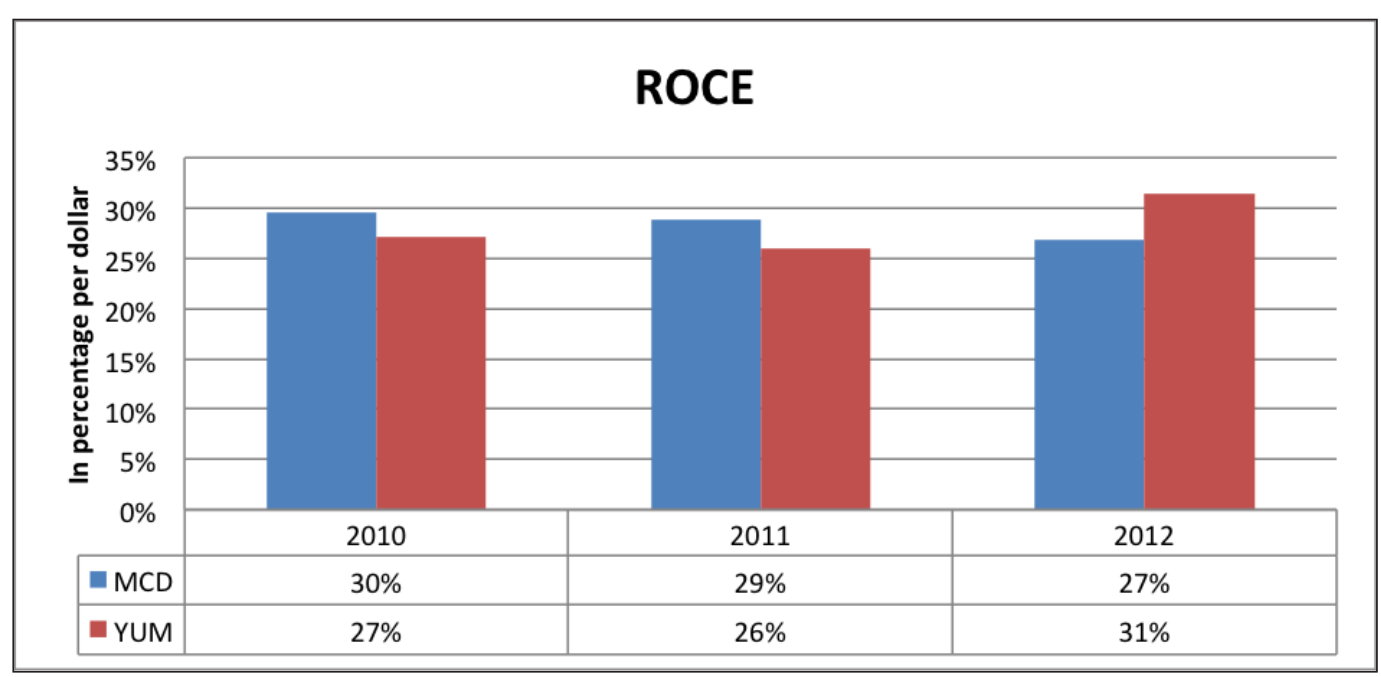

Figure 6: ROCE McDonald's vs. Yum! Brands. 
When we look at the Gross and Net Profit Margins, McDonald's has much higher percentages than Yum! Brands (see Figures 7 and 8). This can be due to the better cost management systems the company has. Gross Profit Margin shows how well the company utilises and allocates its resources. In this case, McDonald's is also doing better. Looking at the Net Profit Margins, we can see that both of the companies surely do well, however Yum! Brands score substantially less than McDonald's. The main reason for such results can be that Yum! Brands have much more liabilities to pay then McDonald's. As we could see from Figure 4, they exceed the assets the company owns; due to this, the Net Profit can be very low after the company pays all of the expenses and its obligations. One can also see that over 3 years both of the companies did not experience dramatic increase or decrease in their Gross and Net Profit Margins; the numbers are nearly the same, which shows stability in their operations.

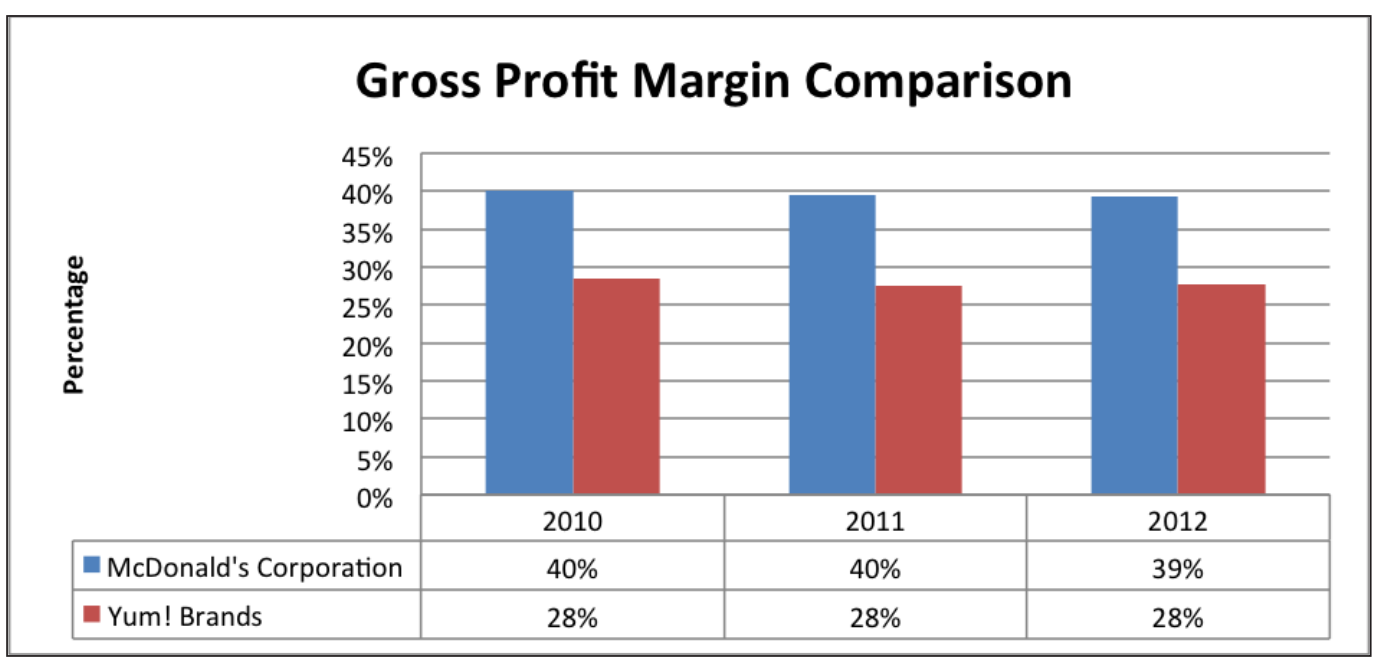

Figure 7: Gross Profit Margin McDonald's vs. Yum! Brands.

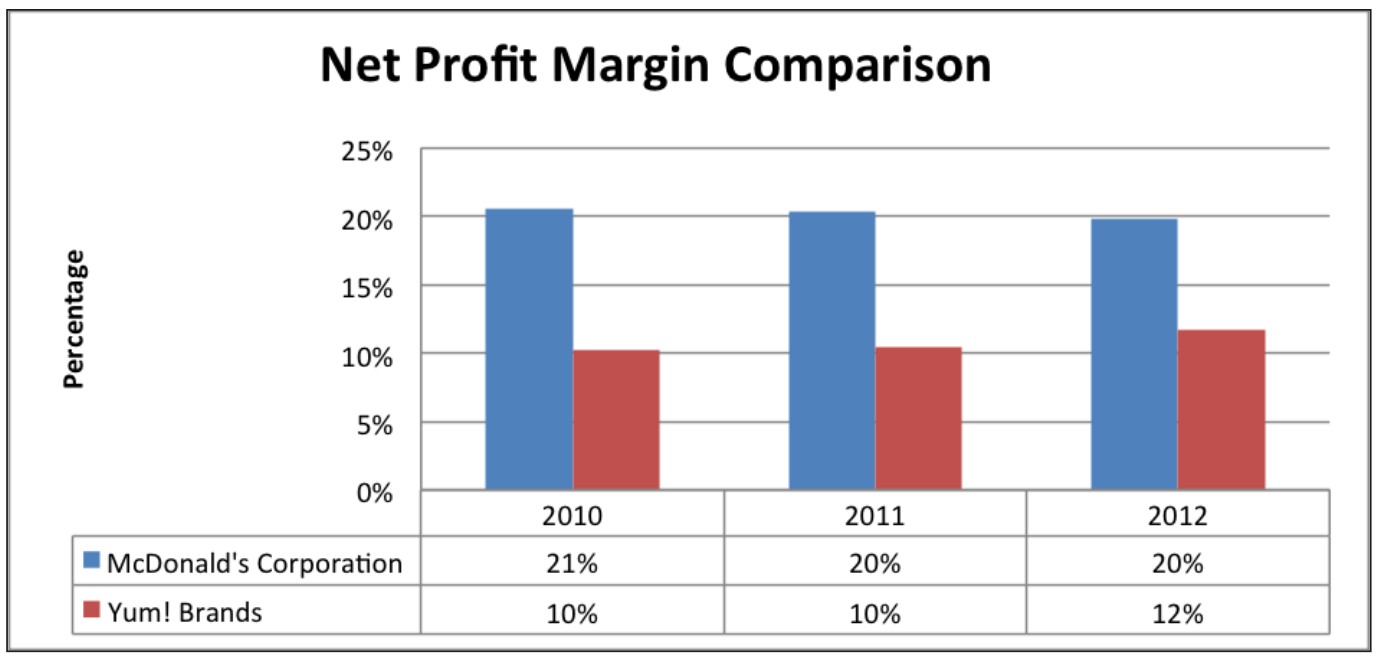

Figure 8: Net Profit Margin McDonald's vs. Yum! Brands. 


\subsection{EFFICIENCY ANALYSIS}

Efficiency ratios show how well the company is using its assets and liabilities. The analysis mainly focuses on the measurement of efficiency by calculating turnover of receivables, fixed assets turnover, and the trade debtor collection period along with creditor payment period. Those ratios are particularly useful when the results are compared between competitors in the same industry. It is also true that change in these ratios directly impact profitability of the organisation.

$$
\text { Stock Turnover }=\frac{\text { Cost of goods sold (Cost of Revenue) }}{\text { Closing stock (Inventory) }}
$$

$$
\text { Fixed assets turnover }=\frac{\text { Sales }(\text { Total Revenue })}{\text { Fixed asstes at net book value (Total Assets) }}
$$

Trade debtor collection period $=\frac{\text { Closing trade debtors }(\text { Net Receivables })}{\text { Credit sales }(\text { Total Revenue })} * 365$

Trade creditor payment period $=\frac{\text { Closing trade creditors }(\text { Accounts Payable })}{\text { Total credit purchases }(\text { Cost of Revenue })} * 365$

The results of the above ratios can be found below:

TABLE 9 - EFFICIENCY RATIOS - MCDONALD'S CORPORATION

\begin{tabular}{|l|r|r|r|}
\hline & $\mathbf{2 0 1 0}$ & $\mathbf{2 0 1 1}$ & $\mathbf{2 0 1 2}$ \\
\hline Cost of Revenue & 14437300 & 16319400 & 16750700 \\
\hline Inventory & 109000 & 116800 & 121700 \\
\hline Stock Turnover & $\mathbf{1 3 2 , 4 5}$ & $\mathbf{1 3 9 , 7 2}$ & $\mathbf{1 3 7 , 6 4}$ \\
\hline Total Revenue & 24074600 & 27006000 & 27567000 \\
\hline Total Assets & 31975200 & 32989900 & 35386500 \\
\hline Fixed Asset Turnover & $\mathbf{0 , 7 5}$ & $\mathbf{0 , 8 2}$ & $\mathbf{0 , 7 8}$ \\
\hline Net Receivables & 1179100 & 1334700 & 1375300 \\
\hline Trade debtor collection period (days) & $\mathbf{1 7 , 8 8}$ & $\mathbf{1 8 , 0 4}$ & $\mathbf{1 8 , 2 1}$ \\
\hline Accounts Payable & 943900 & 961300 & 1141900 \\
\hline Trade creditor collection period (days) & $\mathbf{1 4 , 3 1}$ & $\mathbf{1 2 , 9 9}$ & $\mathbf{1 5 , 1 2}$ \\
\hline
\end{tabular}

\begin{tabular}{|c|c|c|c|}
\hline & 2010 & 2011 & 2012 \\
\hline Cost of Revenue & 8120000 & 9140000 & 9852000 \\
\hline Inventory & 189000 & 273000 & 313000 \\
\hline Stock Turnover & 42,96 & 33,48 & 31,48 \\
\hline Total Revenue & 11343000 & 12626000 & 13633000 \\
\hline Total Assets & 8316000 & 8834000 & 9011000 \\
\hline Fixed Asset Turnover & 1,36 & 1,43 & 1,51 \\
\hline Net Receivables & 317000 & 398000 & 412000 \\
\hline Trade debtor collection period (days) & 10,20 & 11,51 & 11,03 \\
\hline Accounts Payable & 1775000 & 2130000 & 2178000 \\
\hline Trade creditor collection period (days) & 57,12 & 61,58 & 58,31 \\
\hline
\end{tabular}

TABLE 10 - EFFICIENCY RATIOS - YUM! BRANDS 
Looking at the first measure which is Stock Turnover, one can see that McDonald's numbers are higher than those of Yum! Brands (see Figure 9).

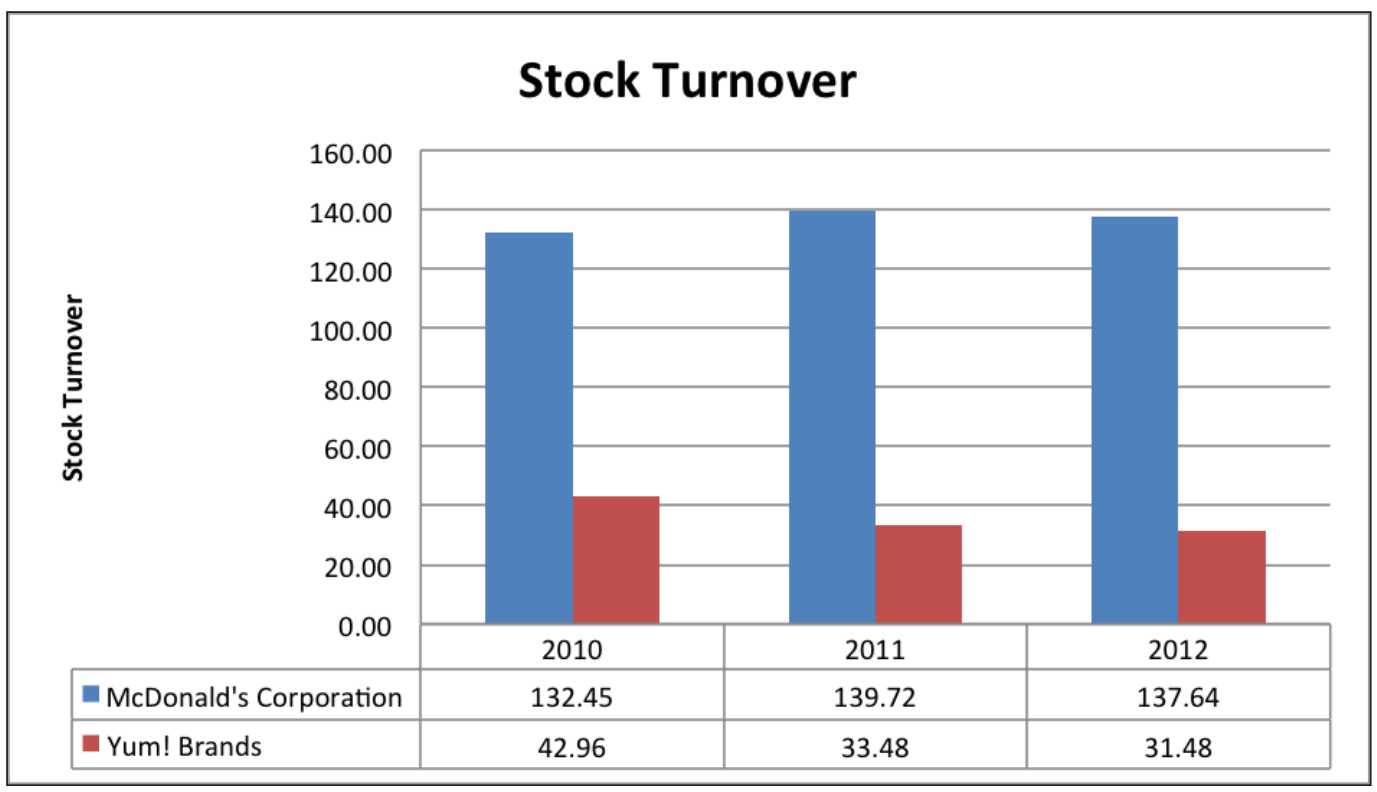

Figure 9: Stock Turnover McDonald's vs. Yum! Brands.

One can see that McDonald's has a positive trend whereas Yum! Brands has experienced a decrease in stock turnover over the 3 year period. The higher the stock turnover, the more efficient the company is in purchasing and selling goods. In this case, if we look at the numbers one can see that the inventory (stock) of McDonald's is actually nearly the same as of Yum! Brands but the Cost of Revenue is extremely higher, and this is the main reason why the results are so different.

The second measure of efficiency is fixed assets turnover (see Figure 10). Fixed assets are used to generate more sales, which means that a higher level of fixed assets tends to generate more sales. In this case the larger the result of the ratio is, the more amount of investment into fixed assets is recovered by the sales. The results can be expressed in percentages. Looking at the results of McDonald's and Yum! Brands (see Figure 10), one can see that Yum! Brands have much higher recovery on the investment into fixed assets.

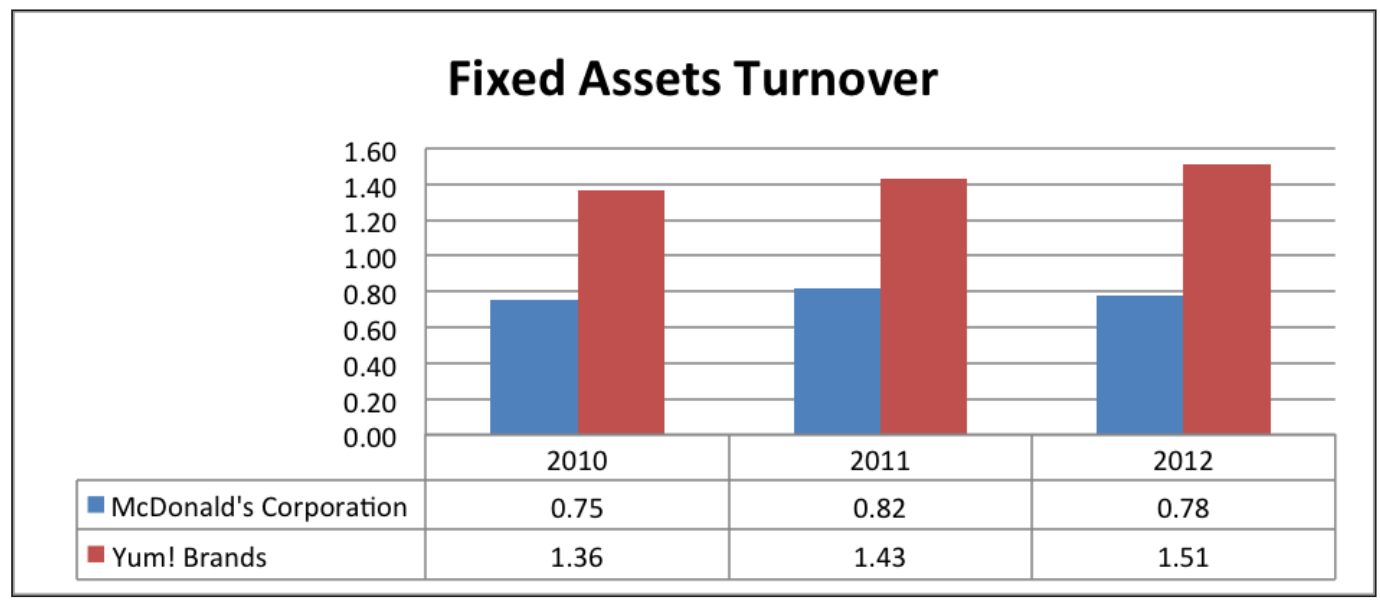

Figure 10: Fixed Assets Turnover McDonald's vs. Yum! Brands. 
Such difference in the results can be caused by the amount of total assets the companies own. In the case of McDonald's, the number of total assets is much higher than the actual revenues. This tells us that with the number of assets McDonald's has, it could produce much more than it does. Whereas with Yum! Brands, the revenues are higher than the assets owned and there is a positive trend in sales.

Looking at the third important area, which is the trade debtor collection period used to determine the period of time a customer is required to pay back for the goods. The higher the result of this ratio is, the bigger the chance that the company will run into cash flow problems and will not be able to cover its sales costs.

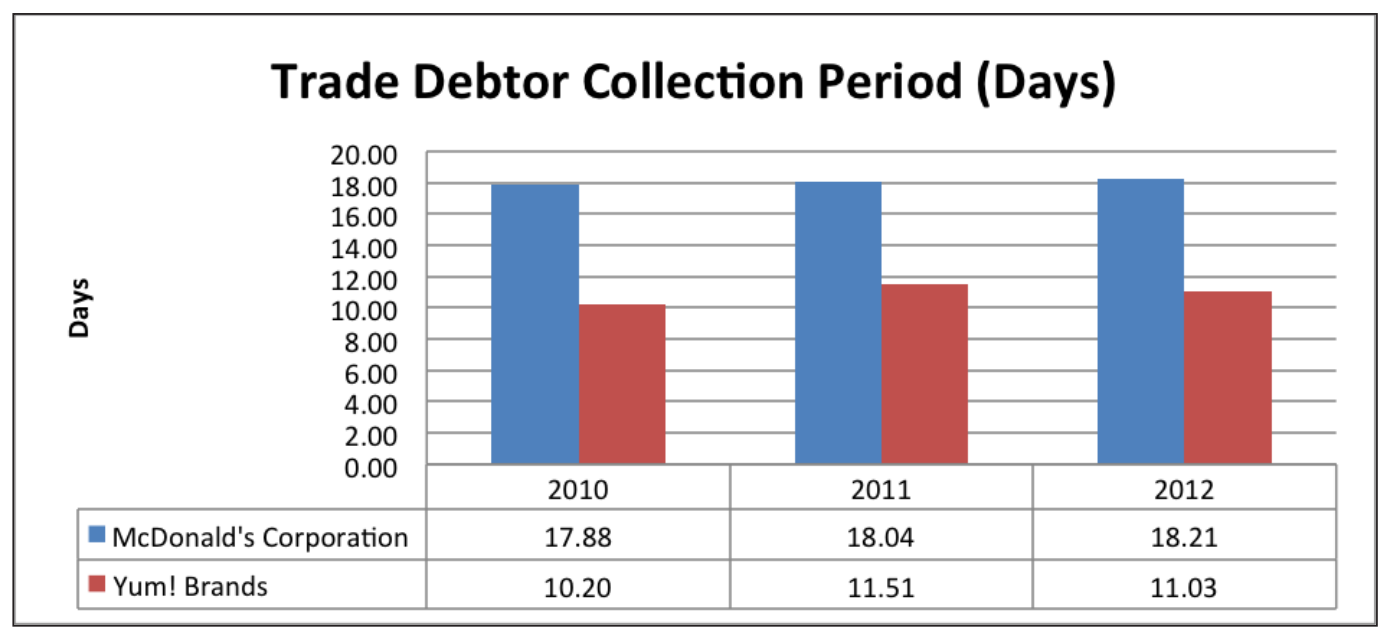

Figure 11: Trade Debtor Collection Period McDonald's vs. Yum! Brands.

As one can see from Figure 11, both of the companies have debtor collection periods lower than 1 month, which is mainly due to the origins of their business. Most of the customers will pay for their products straight away, only the payments from franchisees can come with a delay. From Figure 11 one can also see that,

McDonald's has a higher debtor collection
period in comparison to Yum! Brands; one
of the main reasons why this could happen
is that McDonald's has more headquarters
and franchisees than Yum! Brands. This
makes the number of Net Receivables
higher for McDonald's than for Yum! Brands
as the majority of their customers are end
consumers of the products.

Another criterion in efficiency analysis is trade creditor payment, which tells the settlement period for paying the suppliers. Higher results in this ratio would mean that company is experiencing issues to find a cash to pay its creditors/suppliers. Looking at the results of McDonald's and Yum! Brands in figure 12, one can see that McDonald's has a much lower creditor payment period than Yum! Brands do. 


\section{Trade Creditor Payment Period}

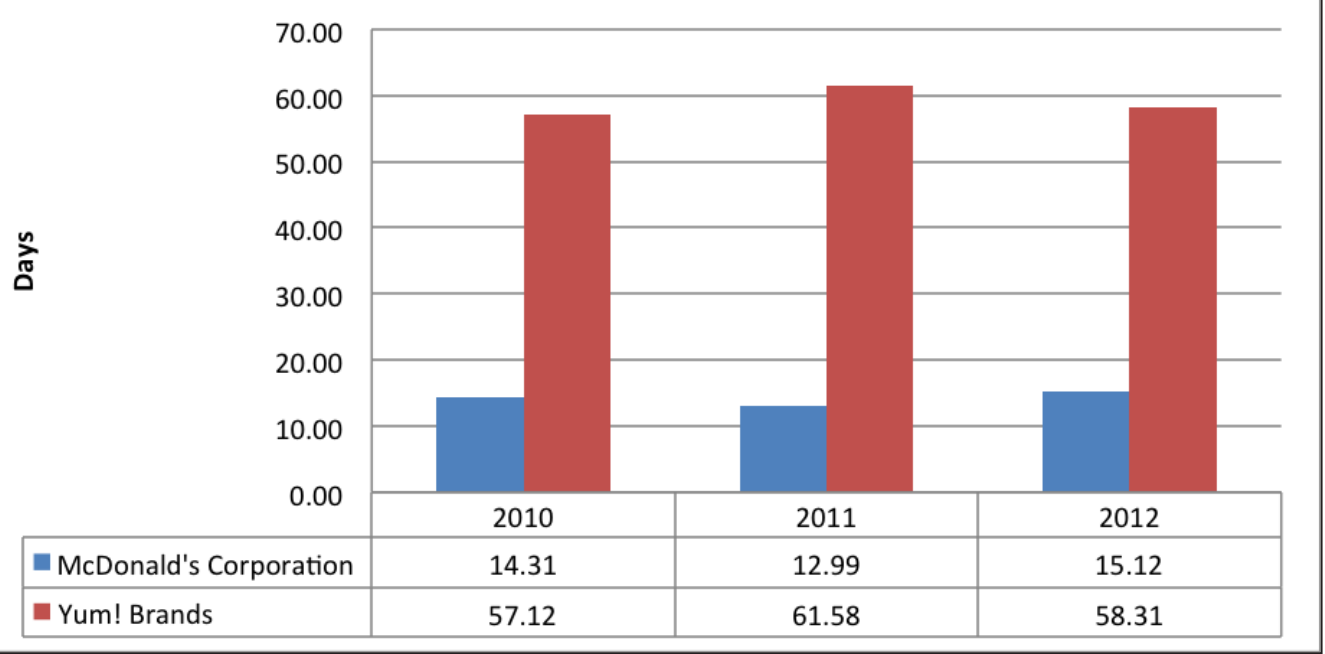

Figure 12:Trade Creditor Payment Period McDonald's vs. Yum! Brands.

One of the reasons why Yum! Brands might have such a high creditor payment period is the amount of liabilities they have to pay (Accounts Payable). Generally it is viewed that a standard credit period is 1 month, and in the case of Yum! Brands it is more than a month, and the result suggests that the company either needs to reduce the amount of liabilities or it has to generate more cash by increasing sales. The results for Yum! Brands correspond to what we have seen previously in Figure 4 and liquidity ratios.

The last metric one can consider in effectiveness analysis is Working Capital Cycle (WCC). In this paper we will calculate working capital cycle using the following formula:

$$
\text { WCC }=\frac{\text { Average Working Captial } * 365}{\text { Total Sales Revenue }}
$$

The results for both of the companies' one can find below:

TABLE 11 - WORKING CAPITAL CYCLE - MCDONALD'S CORPORATION

\begin{tabular}{|l|r|r|r|}
\hline & $\mathbf{2 0 1 0}$ & $\mathbf{2 0 1 1}$ & $\mathbf{2 0 1 2}$ \\
\hline Working Capital & 1443800 & 893800 & 1519000 \\
\hline Total Revenue & 24074600 & 27006000 & 27567000 \\
\hline Working Capital Cycle & $\mathbf{2 1 , 8 9}$ & $\mathbf{1 2 , 0 8}$ & $\mathbf{2 0 , 1 1}$ \\
\hline
\end{tabular}

TABLE 12 - WORKING CAPITAL CYCLE - YUM! BRANDS

\begin{tabular}{|l|r|r|r|}
\hline & $\mathbf{2 0 1 0}$ & $\mathbf{2 0 1 1}$ & $\mathbf{2 0 1 2}$ \\
\hline Working Capital & -135000 & -129000 & 279000 \\
\hline Total Revenue & 11343000 & 12626000 & 13633000 \\
\hline Working Capital Cycle & $\mathbf{- 4 , 3 4}$ & $\mathbf{- 3 , 7 3}$ & $\mathbf{- 7 , 4 7}$ \\
\hline
\end{tabular}

As one can see from Figure 13 and the results, McDonald's has much more WCC than Yum! Brands. The negative results Yum! Brands received were caused by the negative working capital. This as the result means that efficiency of their resources is low and that they might not be able to meet their obligations. 


\subsection{INVESTMENT RATIOS}

Investment ratios are used by investors to estimate the attractiveness of the specific investment. In this section we will look at most widely used ratios:

$$
\text { Dividend Yield }=\frac{\text { Annual Dividend Declared per Share }}{\text { Market Price of Share }} * 100
$$

Earnings Per Share $=\frac{\text { Earnings after tax and dividends(Net Income from Continuing Operations) }}{\text { Common Shares (Outstanding Shares) }}$

$$
\text { Price Earnings Ratio }=\frac{\text { Market Price of the Share }}{\text { EPS }}
$$

(Market price of the share was taken from closing historical prices for each year ending December 1 at Yahoo Finance)

$$
\text { Capital gearing }=\frac{\text { Long }- \text { Term Debt }}{\text { Capital Employed (Total Stockholder Equity) }} \times 100
$$

Where:

Capital Employed $=$ Total Assets - Current Liabilities

The results for the ratios one can find below:

TABLE 13 - INVESTMENT RATIOS - MCDONALD'S CORPORATION

\begin{tabular}{|l|r|r|r|}
\hline & $\mathbf{2 0 1 0}$ & $\mathbf{2 0 1 1}$ & $\mathbf{2 0 1 2}$ \\
\hline Annual Dividend Per Share & 2,26 & 2,53 & 2,87 \\
\hline Market Price of the Share & 76,76 & 100,33 & 88,21 \\
\hline Dividend Yield \% & $\mathbf{2 , 9 4}$ & $\mathbf{2 , 5 2}$ & $\mathbf{3 , 2 5}$ \\
\hline Earnings After Tax and Dividends & 4946300 & 5503100 & 5464800 \\
\hline Outstanding Shares & 1054000 & 1021100 & 1003000 \\
\hline EPS & $\mathbf{4 , 6 9}$ & $\mathbf{5 , 3 9}$ & $\mathbf{5 , 4 5}$ \\
\hline Market Price of the Share & 76,76 & 100,33 & 88,21 \\
\hline Price to Earnings Ratio & $\mathbf{1 6 , 3 6}$ & $\mathbf{1 8 , 6 1}$ & $\mathbf{1 6 , 1 9}$ \\
\hline Long-term Debt & 11497000 & 12133800 & 13632500 \\
\hline Capital Employed & 29050500 & 29480700 & 31983400 \\
\hline Capital Gearing & $\mathbf{4 0 \%}$ & $\mathbf{4 1 \%}$ & $\mathbf{4 3 \%}$ \\
\hline
\end{tabular}

Capital Employed

\begin{tabular}{|l|r|r|r|}
\hline Total Assets & 31975200 & 32989900 & 35386500 \\
\hline Current Liabilities & 2924700 & 3509200 & 3403100 \\
\hline CE & $\mathbf{2 9 0 5 0 5 0 0}$ & $\mathbf{2 9 4 8 0 7 0 0}$ & $\mathbf{3 1 9 8 3 4 0 0}$ \\
\hline
\end{tabular}


TABLE 14 - INVESTMENT RATIOS - YUM! BRANDS

\begin{tabular}{|l|r|r|r|}
\hline & $\mathbf{2 0 1 0}$ & $\mathbf{2 0 1 1}$ & $\mathbf{2 0 1 2}$ \\
\hline Annual Dividend Per Share & 0,92 & 1,07 & 1,24 \\
\hline Market Price of the Share & 49,05 & 59,01 & 66,25 \\
\hline Dividend Yield \% & $\mathbf{1 , 8 8}$ & $\mathbf{1 , 8 1}$ & $\mathbf{1 , 8 7}$ \\
\hline Earnings After Tax and Dividends & 1597000 & 1319000 & 1158000 \\
\hline Outstanding Shares & 469000 & 460000 & 451000 \\
\hline EPS & $\mathbf{3 , 4 1}$ & $\mathbf{2 , 8 7}$ & $\mathbf{2 , 5 7}$ \\
\hline Market Price of the Share & 49,05 & 59,01 & 66,25 \\
\hline Price to Earnings Ratio & $\mathbf{1 4 , 4 0}$ & $\mathbf{2 0 , 5 8}$ & $\mathbf{2 5 , 8 0}$ \\
\hline Long-term Debt & 2915000 & 2997000 & 2932000 \\
\hline Capital Employed & 5868000 & 6384000 & 6823000 \\
\hline Capital Gearing & $\mathbf{5 0 \%}$ & $\mathbf{4 7 \%}$ & $\mathbf{4 3 \%}$ \\
\hline
\end{tabular}

Capital Employed

\begin{tabular}{|l|r|r|r|}
\hline Total Assets & 8316000 & 8834000 & 9011000 \\
\hline Current Liabilities & 2448000 & 2450000 & 2188000 \\
\hline CE & $\mathbf{5 8 6 8 0 0 0}$ & $\mathbf{6 3 8 4 0 0 0}$ & $\mathbf{6 8 2 3 0 0 0}$ \\
\hline
\end{tabular}

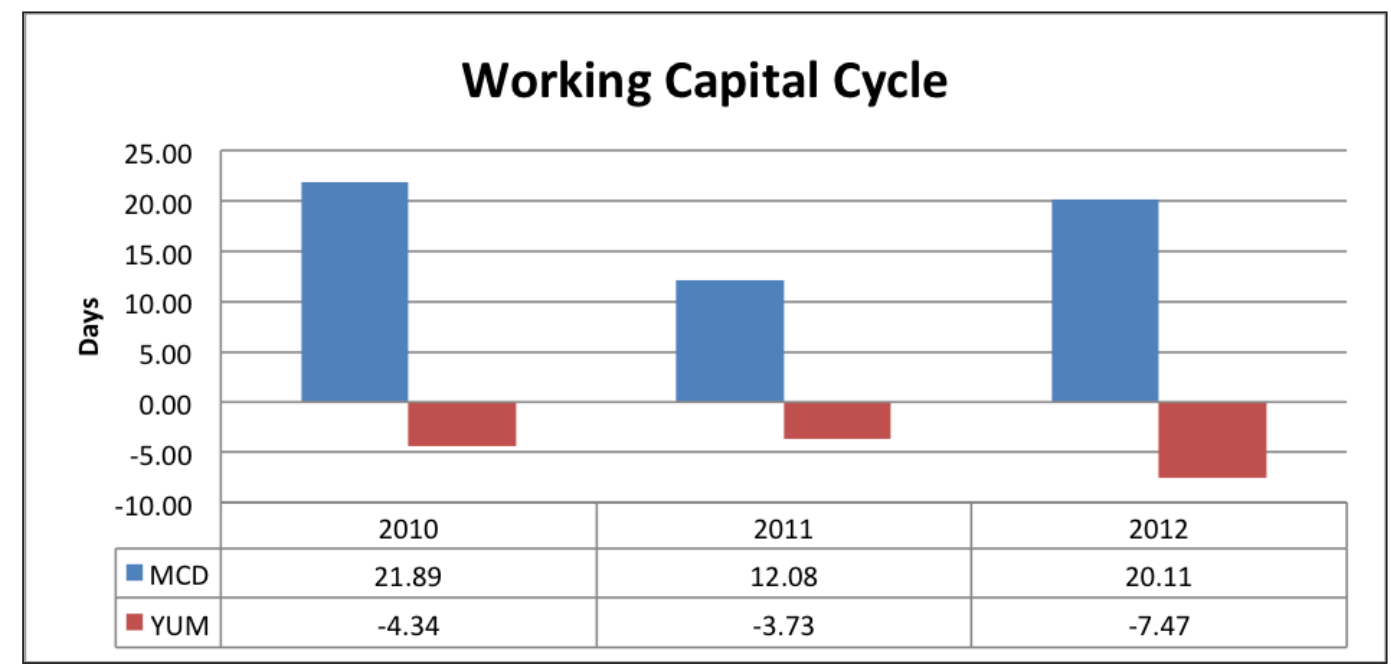

Figure 13: WCC McDonalds vs. Yum! Brands.

To start our comparison, we will firstly look at dividend yield. It shows the productivity of the investment, being more specific, it represents how much cash flow the investor is getting per dollar invested. In the case of McDonald's and Yum! Brands, we can see that Yum! Brands has a lower cash flow per dollar than McDonald's (see Figure 14).

One of the main reasons why McDonald's has higher results is because it has a higher net income from which it can pay higher dividends. This can be a result of efficient cost reduction strategies and utilisation of the equipment, which we have seen from the efficiency ratios. 


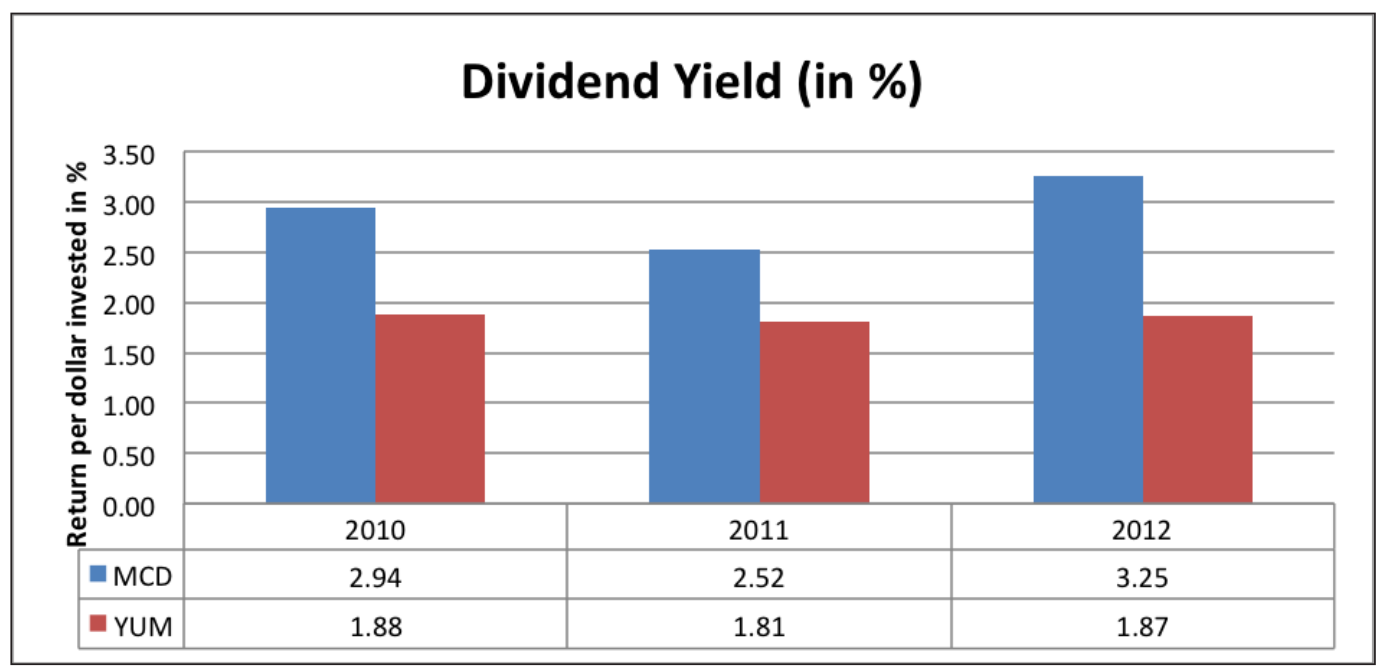

Figure 14: Dividend Yield McDonald's vs. Yum! Brands.

Looking at the EPS of the companies we can see that Yum! Brands EPS is lower than McDonald's. This ratio is very popular between investors as it tells how much the market is willing to pay for a company's earnings. The higher is the ratio, the more the market wants to pay, and the more positive is the prediction for the future growth of the share price. The reason why Yum! Brands have lower EPS can be explained by the relationship between equity and liabilities. As the company has much more liabilities then the equity, it therefore has more expenses and this decreases the net income the from which EPS is calculated. There is also a negative tendency over the years. This can be explained by an increase in the number of shares as the company grows and less increase in earnings. McDonald's in this case is more stable than Yum! Brands.

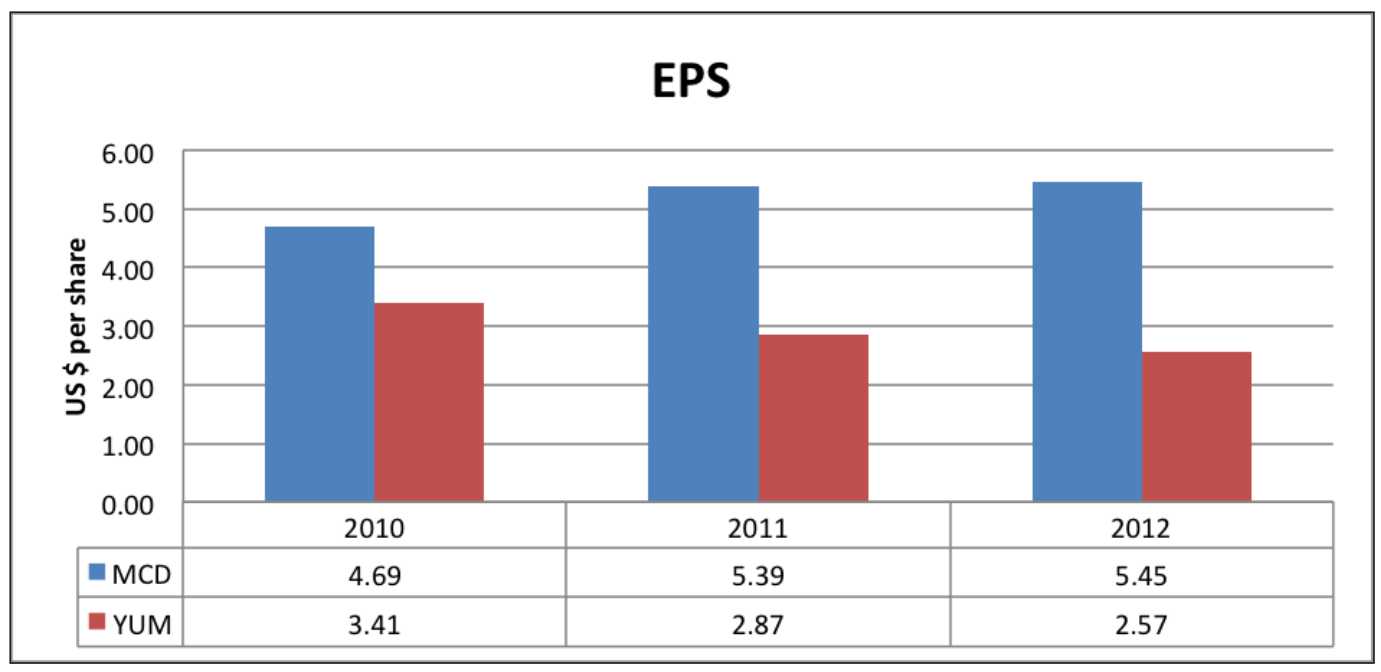

Figure 15: EPS McDonald's vs. Yum! Brands.

The next indicator is Price to Earnings Ratio $(\mathrm{P} / \mathrm{E})$. This indicator is a tricky one as most of the investors tend to forget that the lower is the result of this ratio, the more profitable is the investment. Generally, a value of 12-15 counts to be good. In this case one can see that Yum! Brands are doing much better than McDonald's (see Figure 16) in 2010; however they did much worse in 2011-2012. As this ratios links stock share price with EPS, one of the reasons why Yum! Brands had a change the results might be an increase in the pricing of their shares as they grow, but a less sufficient increase in their EPS. 


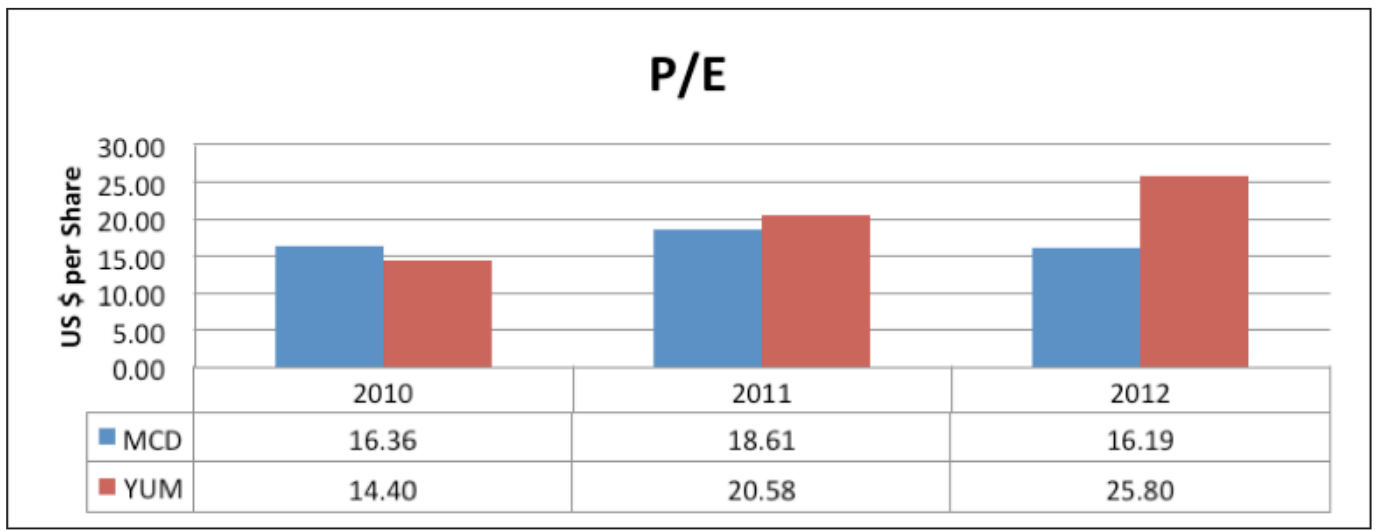

Figure 16: Price to Earnings Ratio McDonald's vs. Yum! Brands.

The next indicator we will look at in this section is the Capital Gearing Ratio. This ratio shows the capital structure of a company and its financial strength. The higher the ratio is, the more risky the investment is since the more activities of the company are supported by borrowed funds, the more interest the company has to pay for its debt. As one can see from Figure 17, Yum! Brands have much higher results than McDonald's, and this corresponds to what we have seen previously as the company has a lot of liabilities and debt. Even though McDonald's has lower results, one should notice that it still has a lot of long-term debt, which can be covered by its capital, but not in full.

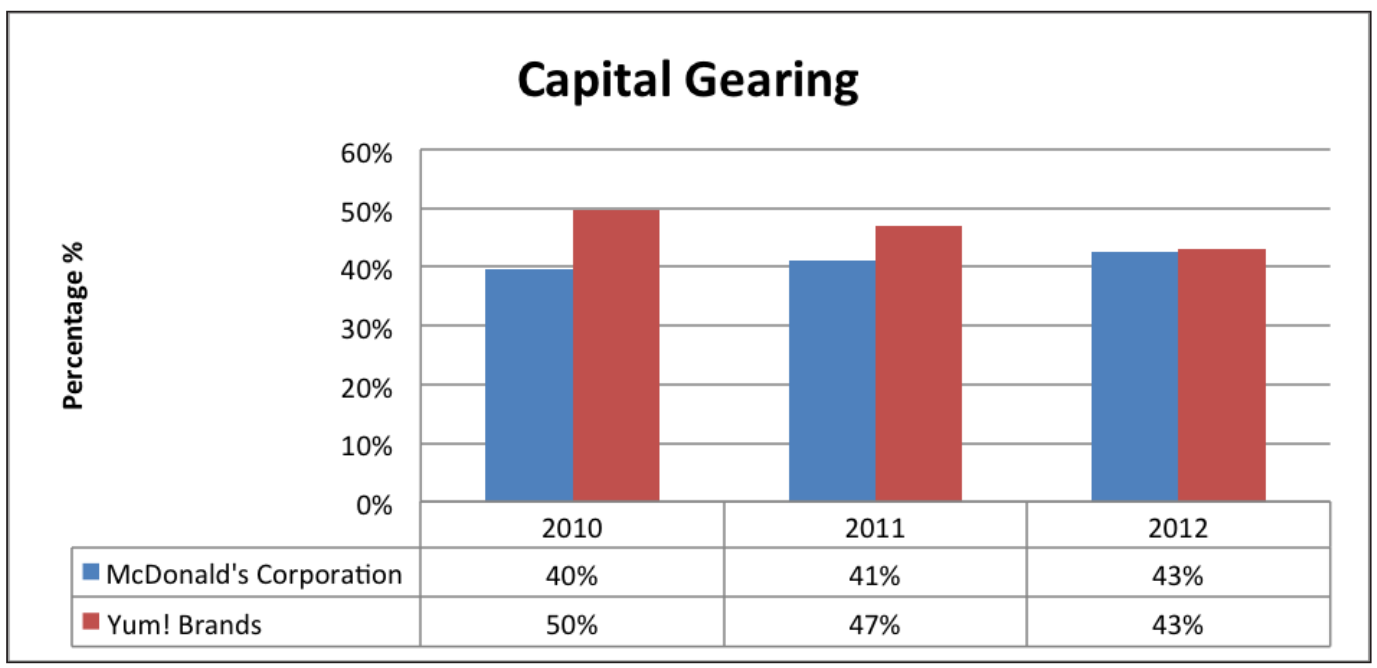

Figure 17: Capital Gearing McDonald's vs. Yum! Brands.

Normally, the ratios for a low-gearing company would be under 25\%, and everything in between 25\%$50 \%$ middle-gearing, and everything over 50\% highly-gearing. As we can see, both McDonald's and Yum! Brands are middle-gearing companies. In this case, McDonald's still performs better than Yum! Brands. One of the main reasons is the long-term debt the company holds and its relationship with the capital employed. As we have seen previously, Yum! Brands have a lot of short-term and long-term liabilities, whereas their assets are not increasing as dramatically as needed; due to this, McDonald's is a safer investment.

It is important to remember that not always financing business through long-term debt gives negative outcomes, as it is most of the times cheap. It would really depend on the ability of the company to raise profits to cover this debt. In this case, both of the companies have great potential, but McDonald's has better performance in meeting its liabilities. 


\section{MCDONALD'S AND YUM! BRANDS VS. INDUSTRIAL AVERAGES}

\subsection{MCDONALD'S VS. YUM! BRANDS STOCK PERFORMANCE EVALUATION}

In this section of the paper we will look at the performance of MCD and YUM stocks over a 3-year period. The author will use SharpCharts from which one could see the volume of the traded stock, the opening and closing price, the change in the price in percentage for the date of $6 \mathrm{Dec} 2013$. One can also find the MACD (Moving Average Convergence-Divergence), Slope charts, MA (50), MA (200), and RSI.

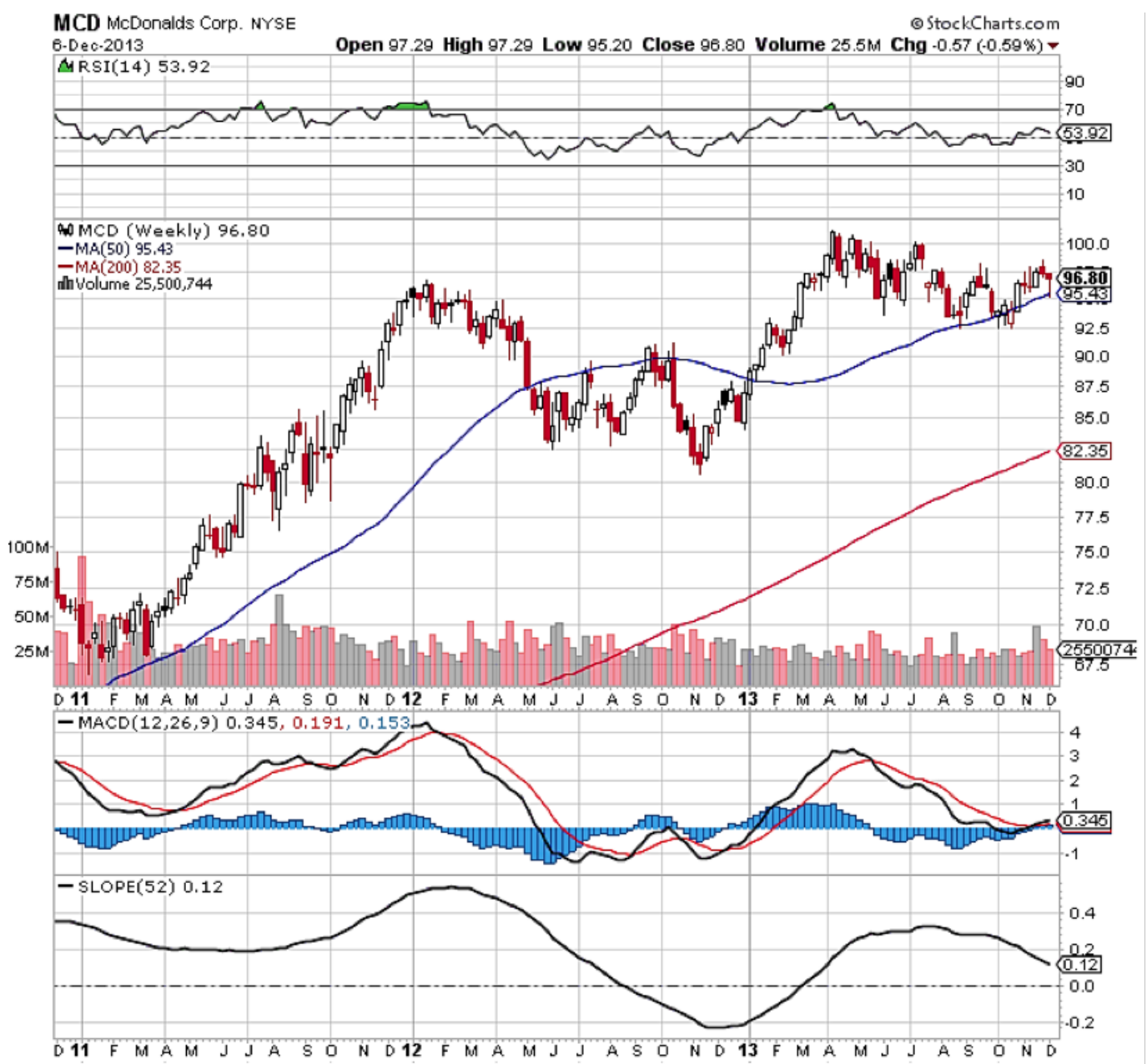

Chart 1: MCD Stock Performance (3 years). Stock Charts (2013)

At the top of Chart 1 one can find the RSI indicator. This indicator stands for Relative Strength Index and is a momentum oscillator. This indicator can vary from zero to 100. RSI can be of different parameters, and in this case the author is using the default 14-day parameter; however, if one needs to increase sensitivity, he/ she should reduce it to 10 days. Since RSI is an oscillator, it determines when the market is overbought or oversold. Generally, it is considered that if RSI is above 70, then it is overbought; if it is less than 30, then it is oversold. If the stock is overbought, then it might experience a decline in price, whereas if it oversold, it has potential to grow in the future. Investors use RSI to identify the best time to sell or buy financial assets. When the asset is approaching 70, it is beneficial to sell it, whereas if the stock is approaching 30, it is time to buy. As one can see both YUM and MCD are stable stocks. 
As one can see from Charts 1 and 2, the results for MCD and YUM are not falling into any of the categories. In the Chart 1, one can see the blue and the red lines which stand for moving averages (MA). This indicator helps to better analyse the price movement by eliminating 'noise' from random price fluctuations. This indicator is based on previous prices due to sometimes it can lack accuracy. Generally, there are two types of MAs, SMA (Simple Moving Average) and EMA (Exponential Moving Average). The main difference between the two is that EMA gives bigger weight to more recent prices. In this report, we will consider SMA for the period of time of 50 days and 200 days, represented respectively by blue and red lines.

As one can see, the SMA for the 50 days period is much higher than SMA for 200 days. MA (50) has the price of $\$ 95.43$ and SMA (200) only \$82.35. MA for a shorter period of time will have smaller lag than MA for a longer period such as 200 days. Therefore, short-term investors would prefer to refer to short-term MAs whereas long-term investors generally prefer to look at a long-term MA.

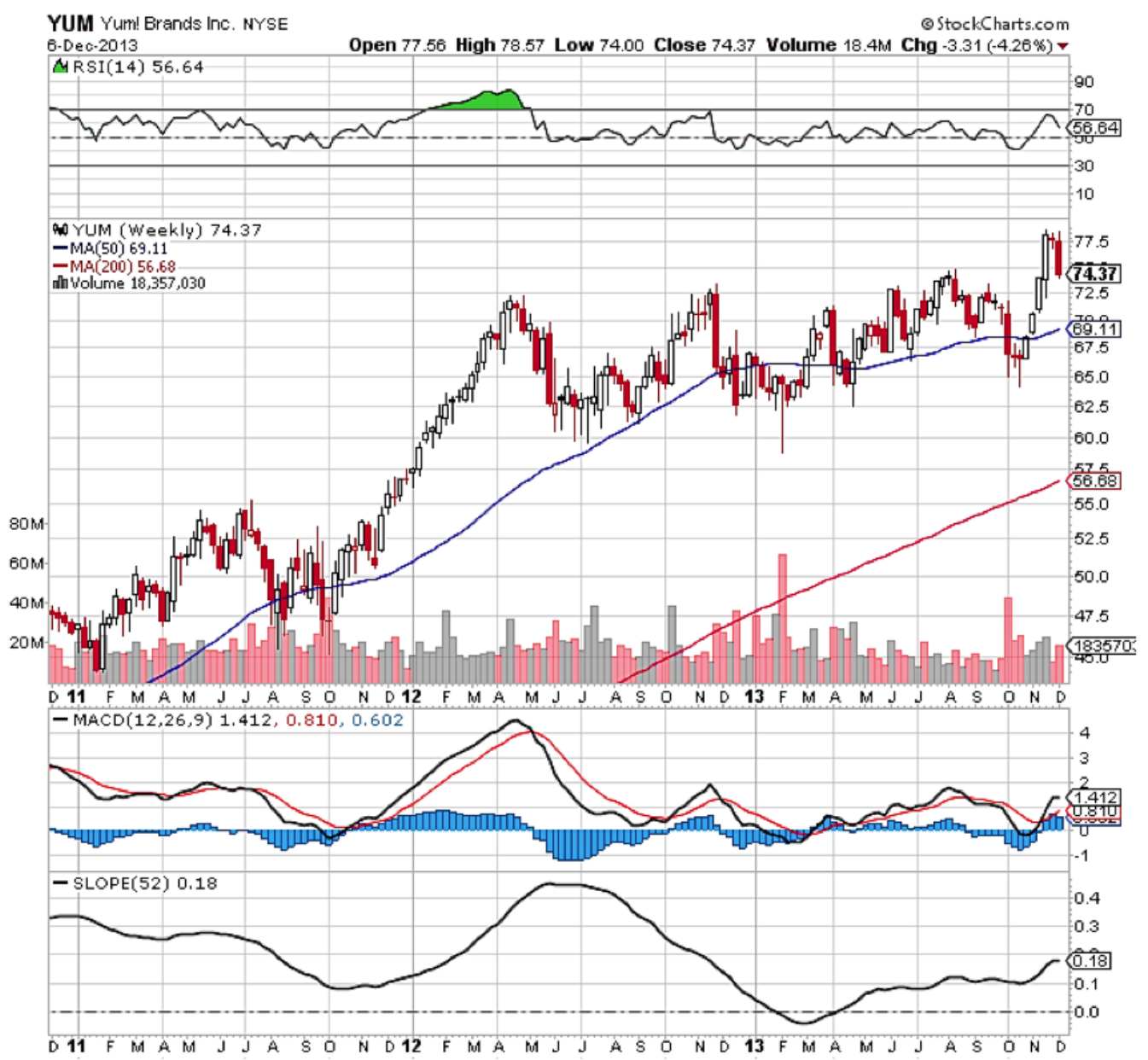

Chart 2: YUM! Stock Performance (3 years). Stock Charts (2013)

Even though the prices for MA (200) is lower, it is still on the uptrend, which indicates that the security has growth. One can also see that in the MCD case, the long-term MA and the short-term MA did not crossover, which indicates that overall the performance is on a steady growth path. Comparing MCD, MA (50) and (200) with the results for YUM represented in Chart 2, one can see that the averages are smaller for YUM- MA (50) - 69.11 and MA (200) - 56.68. One can also see the same tendency that MA (50) is larger than MA (200), and the author assumes that one of the reasons for this is the lag. Both of the companies though have a positive uptrend over the 3 years. 
MA is not only a single indicator but also a contributor to the next measure which is Moving Average Convergence-Divergence (MACD). This indictor, which one can see represented in both Charts 1 and 2 below the main body, is counted to be the easiest momentum indicator. What it does is it subtracts longer moving average from the shorter moving average. The shorter the period under study, the more sensitive are the results. In this report we will use the standard setting $(12,26,9)$. The investors tend to look for the signal lines crossovers, centerline crossovers, and divergences to generate signals. Since MACD is based on concepts of convergence and divergence, it is important to mention that convergence occurs when the MAs move towards each other and divergence occurs when they move away from each other. As one can see from Charts 1 and 2, both of the companies have convergence in the movement of the MAs. One can also see that the averages are higher for YUM than for MCD as it experienced a negative performance during the second half of the year 2012 until 2013.

The last indicator in this section, the scope, is a result of linear regression which generates the line of best fit for a price series. This indicator is a good tool to measure the direction and strength of a trend. Investors can also use it in combination with other tools to identify the potential point of entry to the already on-going trend. The trend can fluctuate above and below zero. In this paper the author took the 52-week slope. As one can see, MCD has a positive trend until the first quarter of 2012 first when it experienced a decline which one could also see in the results of the ratios for the previous sections. From the third quarter of year 2013 until the first quarter of 2013 MCD was in negative territory; however, then it experienced growth. As for the YUM! Brands one can see that the trend is much more positive and the period where they performed under the positive region is shorter (only the first quarter of 2013). If we look at the average YUM has 0.18 and MCD 0.12, which means that YUM has a more positive price trend than MCD.

\subsection{INDUSTRY COMPARISON}

In this section of the paper, the author will compare stock performance of YUM and MCD to each other as well as to the industry indices like SerP 500 and Down Jones. In Chart 3 one can see the comparison of MCD and YUM, and SerP 500, and DJ Indices stock performance. SerP 500 stands for Standard er Poor's 500 Index. This index consists of 500 stocks which are chosen by market size, liquidity, etc. This index is meant to be the leading indicator of the U.S. stock market. Previously, it was the Down Jones Index which is also represented in Chart 3 in red; however, since DJ includes only 30 companies, SerP 500 is considered to be the best representation. Both of the indices are appropriate for this specific comparison since we are evaluating companies which are listed in the NYSE.

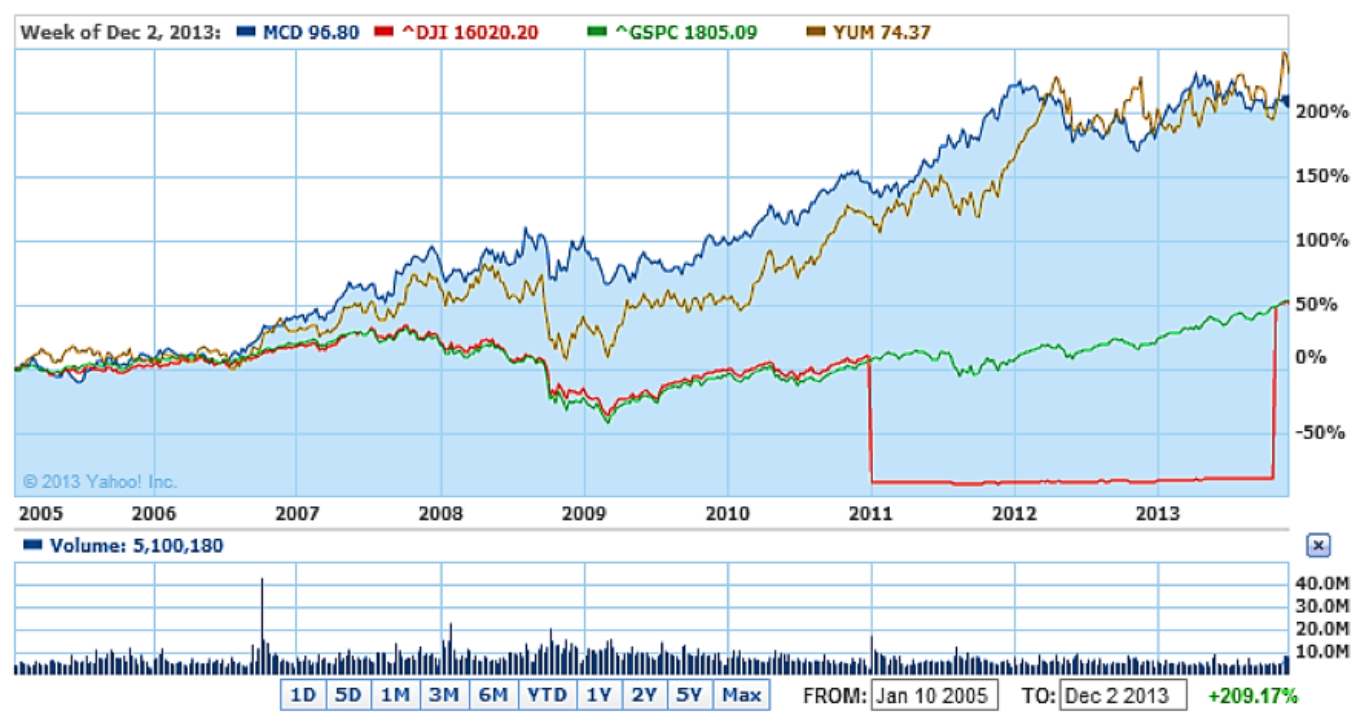


When we look at Chart 3 one can see that both MCD and YUM outperform SerP 500 and DJ indices, which shows that generally both of the companies have higher growth than the competitors and are attractive to investors. If one compares the performance of MCD to YUM, we can see that through the years 20072012 MCD has the highest prices and the best stock performance. However, starting in 2012 we can see that YUM is actually performing at the same level with periodic crossover. It is essential to highlight here that both of the companies are the benchmarks of the industry and of course even when they experience a decrease in their prices, they can outperform the competitors, as one can see from Chart 4.

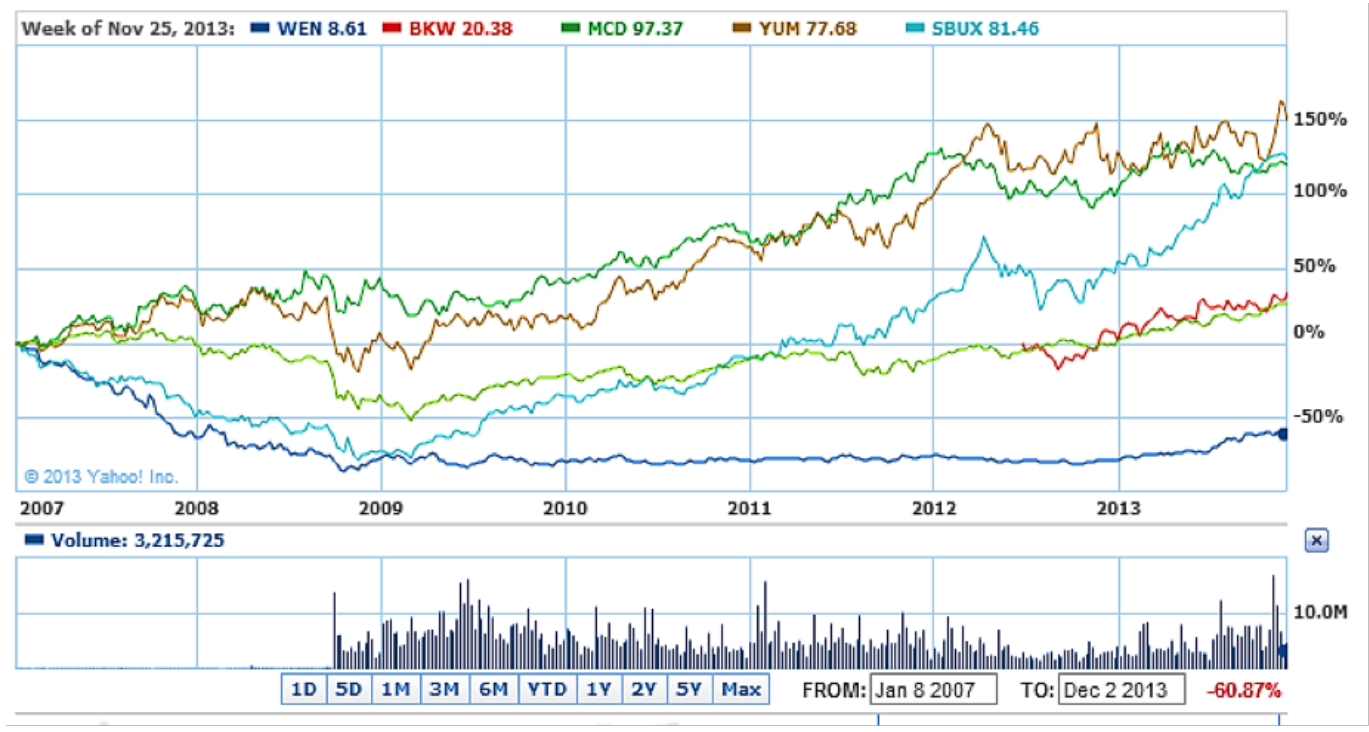

Chart 4: Comparison to Direct Competitors. Yahoo Finance (2013).

In Chart 4 one can see the comparison of several stocks, which are directly competing with MCD and YUM. Those are stock of companies - Wendy e Corporation, Burger King, and Starbucks. The chart also shows SerP 500 represented by a light-green line. As one can see, starting end of 2007 beginning of 2008, when the U.S. market experienced a crisis, the performance of SerP 500 and YUM and MCD are dramatically different.

\section{As S\&P 500 shows most of the companies experienced a decline in their stock performance; however, for MCD and YUM we can see a positive trend. When we look at Wendy's Corporation, we can see that starting in the year 2007, it experienced a decline and after this, it did not experience any major growth and is beyond the S\&P 500 index.}

Whereas Starbucks after experiencing a decline in the years during the crisis, experienced growth and still has a positive trend, even though it is still has lower stock prices than YUM and MCD. When we look at Burger King, the data is available only starting in the year 2012, and we can see that the stock performance is nearly the same as of SerP 500. Comparing all of the stocks one can see that MCD and YUM outperform all of their competitors and also the SerP 500 Index. 


\subsection{FINANCIAL RATIOS MCDONALD'S AND YUM! BRANDS INDUSTRY COMPARISON}

In this section the author will compare the two companies with industrial averages for a set of ratios which are usually used by investors to evaluate the performance of the stock. The author of the report referred to Morning Stars' (2013) estimates, which one can find below:

\section{FIGURE 18 - - MCD AND YUM! VALUATION}

\begin{tabular}{|l|r|r|r|}
\hline & MCD & YUM & Industry Avg. \\
\hline Price/Earnings & 17.4 & 32.5 & 29.5 \\
\hline Price/Book & 6.3 & 15.8 & 7.7 \\
\hline Price/Sales & 3.5 & 2.8 & 2.5 \\
\hline Price/Cash Flow & 13.7 & 17.7 & 11.6 \\
\hline Dividend Yield \% & 3.2 & 1.8 & 1.9 \\
\hline
\end{tabular}

When we look at the $\mathbf{P} / \mathbf{E}$ ratio, one can see that industry average for this metric is 29.5 , high $\mathrm{P} / \mathrm{E}$ ratio is less attractive for investors as it means that they are paying more for the earnings. In this case, Yum! Brands is more attractive for the value investors, who a looking for undervalued stocks, with the potential growth, whereas McDonald's would be desirable for growth investors who are looking for the stock with high growth rates. Yum! Brands shows higher results than the industry average and this means that the company might face issues with solvency.

Price/Book ratio provides an understanding if the stock is overvalued or undervalued. As one can see Yum! Brands score much higher than McDonald's and the industry average, which might mean that the stock is overpriced or investors have high expectations. McDonald's in this case scores lower than the industry average, which means that the stock is underpriced, due to lower growth expectation associated with it, whereas Yum! Brands exceeds the industry average which might mean that it is overvalued.

Price/S compares the value of the stock to either its own performance in the past or to other companies. It determines how much investors pay for the dollar of company's sales. Therefore, the lower the ratio is, the more attractive the stock is. This measure can be very useful only when comparing to the industry average, and in this case, the industry average is 2.5, as we can see both Yum! Brands and McDonald's score higher than this, but Yum! Brands is performing better than McDonald's.

$\mathbf{P} / \mathbf{C}$ metric compares stock market price to cash flow generated per-share. This ratio is similar to $P / E$, however a lot of investors consider it much more solid. The main reason behind this is that cash flow is generally harder to manipulate, whereas earnings are affected by such factors like depreciation. The same way as the $\mathrm{P} / \mathrm{E}$ ratio, the lower the results, the better. The industry average for this ratio is 9.6 which both of the companies outperform. However, McDonald's has lower scores than Yum! Brands. These results correspond to the working capital issues Yum! Brands currently has.

When we look at the last metrics, Dividend Yield, which represents the return (in percentage) the company pays out in dividends. The average for this metrics is 1.9\%, which is higher than what Yum! Brands pays out. McDonald's, though, exceeds this amount and it pays 3.2\%. It is important to notice here that generally older companies tend to pay higher dividends, and their dividends history tends to be more stable.

To summarise the above, the author wants to highlight that generally McDonald's is performing better than Yum! Brands. It is more stable and has better return on the investment. As in most of the ratios, it scored less than Yum! Brands. Even though Yum! Brands show concerns in areas of cash flow, working capital and debt, their growth rates are high and are increasing from 2012. This might help the companies to increase revenues to cover liabilities. 


\section{CONCLUSIONS}

In this paper the author has performed financial analyses for McDonald's and Yum! Brands. She has compared the results of the liquidity, profitability, efficiency, and investment ratios as well as looked at the industrial averages to better evaluate the companies' performance.

From the above analyses, the author can conclude that McDonald's performed much better than Yum! Brands in all of the areas investigated. Yum! Brands are experiencing issues with working capital and might face problems with covering their short-term and long-term liabilities. They are also less efficient in managing their costs of production, even though they utilise their assets better than McDonald's. Yum! Brands performed better in ROCE in 2012 due to an increase in their Gross Profit; however, they have a lower Net Profit Margin than McDonald's. This can be explained by the expenses the company encounters and their costs management and pricing systems. Another reason why McDonald's performed better nearly in all profitability ratios was because of the number of liabilities Yum! Brands need to pay. As we have seen from the liquidity ratios, those exceed their assets.

If we look at the efficiency ratios, McDonald's has higher debtor collection period and lower fixed asset turnover than YUM, but the company still does not have problems with the Working Capital Cycle. It also performs better in the creditor collection period, which shows that the company has enough cash to pay to its creditors in the short-term.

When one considers investment ratios, he/she can see that McDonald's also scored better. It has a lower $\mathrm{P} / \mathrm{E}$ ratio meaning that investors pay less for the earnings they receive than Yum! Brands. Its EPS is higher and therefore the Dividend Yield is also higher than that of Yum! Brands, and exceeds the industry average. Its Capital Gearing Ratio shows that it is a low-gearing company and is less risky as an investment. If we look at the stock performance one can see that McDonald's has a positive trend of growth and outperforms the SerP 500 and DJ Indices. It also outperforms all of the competitors in its sector, including Burger King and Wendy's Corporation. However, when we look at Yum! Brands we can see that they entered into competition with McDonald's in 2012, and in the future it can be a very attractive stock to invest in for the growth investors. McDonald's, on the other hand, would be an option for value investors who are seeking for long-term investments. 


\section{REFERENCES}

Yahoo Finance (2013) Financials McDonald's Corporation. Available at: http://finance.yahoo.com/q/is?s=MCD+Income+S tatementerannual (Accessed: 1 November 2013).

Yahoo Finance (2013) Financials Yum! Brands. Available at: http://finance.yahoo.com/q/is?s=YUM+Income+Statement erannual (Accessed: 1 November 2013).

Morning Star (2013) McDonald's Corporation MCD. Available at: http://financials.morningstar.com/valuation/price-ratio. html?t=MCDerregion=USAerculture=en-US (Accessed: 11 November 2013).

Morning Star (2013) Yum Brands Inc. Available at: http://financials.morningstar.com/valuation/price-ratio. html?t=YUMerregion=USAerculture=en-US (Accessed: 11 November 2013).

Yahoo Finance (2013) Historical Prices: MCD. Available at: http://finance.yahoo.com/q/hp?s=MCD+Historical+Prices (Accessed: 11 November 2013).

Yahoo Finance (2013) Historical Prices: Yum! Brands. Available at: http:/ /finance.yahoo.com/q/ hp?s=YUM+Historical+Prices (Accessed: 11 November 2013).

Stock Charts (2013) SharpCharts. Available at: http:/ /stockcharts.com/h-sc/ui?s=mcd (Accessed: 7 December 2013)

McDonald's Corporation (2013) Annual Report 2012. Available at: http://www.aboutmcdonalds.com/content/dam/ AboutMcDonalds/Investors/Investor\%202013/2012\%20Annual\%20Report\%20Final.pdf (Accessed: 29 November 2013).

Yum! Brands (2013) Annual Report 2012. Available at: http://yum.com/annualreport/pdf/2012yumAnnReport.pdf (Accessed: 29 November 2013). 


\section{APPENDIX 1 - MCDONALD'S CORPORATION}

\begin{tabular}{|c|c|c|c|}
\hline Income Statement & \multicolumn{2}{|c|}{ Get Income Statement for: } & GO \\
\hline \multicolumn{2}{|l|}{ View: Annual Data | Quarterly Data } & \multicolumn{2}{|c|}{ All numbers in thousands } \\
\hline Period Ending & Dec 31, 2012 & Dec 31, 2011 & Dec 31, 2010 \\
\hline Total Revenue & $27,567,000$ & $27,006,000$ & $24,074,600$ \\
\hline Cost of Revenue & $16,750,700$ & $16,319,400$ & $14,437,300$ \\
\hline Gross Profit & $10,816,300$ & $10,686,600$ & $9,637,300$ \\
\hline \multicolumn{4}{|l|}{ Operating Expenses } \\
\hline Research Development & - & - & - \\
\hline Selling General and Administrative & $2,203,700$ & $2,160,800$ & $2,135,100$ \\
\hline Non Recurring & 8,000 & $(3,900)$ & 29,100 \\
\hline Others & - & - & - \\
\hline Total Operating Expenses & - & - & - \\
\hline Operating Income or Loss & $8,604,600$ & $8,529,700$ & $7,473,100$ \\
\hline \multicolumn{4}{|l|}{ Income from Continuing Operations } \\
\hline Total Other Income/Expenses Net & $(9,000)$ & $(24,700)$ & $(21,900)$ \\
\hline Earnings Before Interest And Taxes & $8,595,600$ & $8,505,000$ & $7,451,200$ \\
\hline Interest Expense & 516,600 & 492,800 & 450,900 \\
\hline Income Before Tax & $8,079,000$ & $8,012,200$ & $7,000,300$ \\
\hline Income Tax Expense & $2,614,200$ & $2,509,100$ & $2,054,000$ \\
\hline Minority Interest & - & - & - \\
\hline Net Income From Continuing Ops & $5,464,800$ & $5,503,100$ & $4,946,300$ \\
\hline \multicolumn{4}{|l|}{ Non-recurring Events } \\
\hline Discontinued Operations & - & - & - \\
\hline Extraordinary Items & - & - & - \\
\hline Effect Of Accounting Changes & - & - & - \\
\hline Other Items & - & - & - \\
\hline Net Income & $5,464,800$ & $5,503,100$ & $4,946,300$ \\
\hline Preferred Stock And Other Adjustments & - & - & - \\
\hline Net Income Applicable To Common Shares & $5,464,800$ & $5,503,100$ & $\overline{4,946,300}$ \\
\hline
\end{tabular}

\begin{tabular}{|c|c|c|c|c|c|}
\hline \multirow{2}{*}{$\begin{array}{l}\text { Income Statement } \\
\text { Income Statement }\end{array}$} & \multirow{2}{*}{$\begin{array}{l}\text { Cash Flow } \\
2012\end{array}$} & \multicolumn{2}{|c|}{ Balance Sheet } & Credit Rating & \multirow[b]{2}{*}{2008} \\
\hline & & 2011 & 2010 & 2009 & \\
\hline Revenue & $\$ 27,567$ & $\$ 27,006$ & $\$ 24,074.6$ & $\$ 22,744.7$ & $\$ 23,522.4$ \\
\hline Gross Profit & $\$ 10,816.3$ & $\$ 10,686.6$ & $\$ 9,637.3$ & $\$ 8,791.8$ & $\$ 8,639.2$ \\
\hline Operating Income & $\$ 8,604.6$ & $\$ 8,529.7$ & $\$ 7,473.1$ & $\$ 6,841$ & $\$ 6,442.9$ \\
\hline Net Income & $\$ 5,464.8$ & $\$ 5,503.1$ & $\$ 4,946.3$ & $\$ 4,551$ & $\$ 4,313.2$ \\
\hline Diluted EPS & $\$ 5.36$ & $\$ 5.27$ & $\$ 4.58$ & $\$ 4.11$ & $\$ 3.76$ \\
\hline
\end{tabular}




\begin{tabular}{|c|c|c|c|}
\hline Balance Sheet & & Get Balance Sheet for: [ & GO \\
\hline View: Annual Data | Quarterly Data & & & All numbers in thousands \\
\hline Period Ending & Dec 31, 2012 & Dec 31, 2011 & Dec 31, 2010 \\
\hline \multicolumn{4}{|l|}{ Assets } \\
\hline \multicolumn{4}{|l|}{ Current Assets } \\
\hline Cash And Cash Equivalents & $2,336,100$ & $2,335,700$ & $2,387,000$ \\
\hline Short Term Investments & - & - & - \\
\hline Net Receivables & $1,375,300$ & $1,334,700$ & $1,179,100$ \\
\hline Inventory & 121,700 & 116,800 & 109,900 \\
\hline Other Current Assets & $1,089,000$ & 615,800 & 692,500 \\
\hline Total Current Assets & $\mathbf{4}, 922,100$ & $\mathbf{4 , 4 0 3 , 0 0 0}$ & $4,368,500$ \\
\hline Long Term Investments & $1,380,500$ & $1,427,000$ & $1,335,300$ \\
\hline Property Plant and Equipment & $24,677,200$ & $22,834,500$ & $22,060,600$ \\
\hline Goodwill & $2,804,000$ & $2,653,200$ & $2,586,100$ \\
\hline Intangible Assets & - & - & - \\
\hline Accumulated Amortization & - & - & - \\
\hline Other Assets & $1,602,700$ & $1,672,200$ & $1,624,700$ \\
\hline Deferred Long Term Asset Charges & - & - & - \\
\hline Total Assets & $35,386,500$ & $32,989,900$ & $31,975,200$ \\
\hline \multicolumn{4}{|l|}{ Liabilities } \\
\hline \multicolumn{4}{|l|}{ Current Liabilities } \\
\hline Accounts Payable & $3,403,100$ & $3,142,600$ & $2,916,400$ \\
\hline Short/Current Long Term Debt & - & 366,600 & 8,300 \\
\hline Other Current Liabilities & - & - & - \\
\hline Total Current Liabilities & $3,403,100$ & $3,509,200$ & $2,924,700$ \\
\hline Long Term Debt & $13,632,500$ & $12,133,800$ & $11,497,000$ \\
\hline Other Liabilities & $1,526,200$ & $1,612,600$ & $1,586,900$ \\
\hline Deferred Long Term Liability Charges & $1,531,100$ & $1,344,100$ & $1,332,400$ \\
\hline Minority Interest & - & - & - \\
\hline Negative Goodwill & - & - & - \\
\hline Total Liabilities & $20,092,900$ & $18,599,700$ & $17,341,000$ \\
\hline \multicolumn{4}{|l|}{ Stockholders' Equity } \\
\hline Misc Stocks Options Warrants & - & - & - \\
\hline Redeemable Preferred Stock & - & - & - \\
\hline Preferred Stock & - & - & - \\
\hline Common Stock & 16,600 & 16,600 & 16,600 \\
\hline Retained Earnings & $39,278,000$ & $36,707,500$ & $33,811,700$ \\
\hline Treasury Stock & $(30,576,300)$ & $(28,270,900)$ & $(25,143,400)$ \\
\hline Capital Surplus & $5,778,900$ & $5,487,300$ & $5,196,400$ \\
\hline Other Stockholder Equity & 796,400 & 449,700 & 752,900 \\
\hline Total Stockholder Equity & $15,293,600$ & $14,390,200$ & $14,634,200$ \\
\hline Net Tangible Assets & $12,489,600$ & $11,737,000$ & $12,048,100$ \\
\hline
\end{tabular}

\begin{tabular}{|c|c|c|c|}
\hline Cash Flow & & Get Cash Flow for: [ & GO \\
\hline View: Annual Data | Quarterly Data & \multicolumn{3}{|c|}{ All numbers in thousands } \\
\hline Period Ending & Dec 31, 2012 & Dec 31, 2011 & Dec 31, 2010 \\
\hline Net Income & $5,464,800$ & $5,503,100$ & $4,946,300$ \\
\hline \multicolumn{4}{|c|}{ Operating Activities, Cash Flows Provided By or Used In } \\
\hline Depreciation & $1,488,500$ & $1,415,000$ & $1,276,200$ \\
\hline Adjustments To Net Income & 135,900 & 192,000 & 248,100 \\
\hline Changes In Accounts Receivables & $(29,400)$ & $(160,800)$ & $(50,100)$ \\
\hline Changes In Liabilities & $(66,500)$ & 253,000 & $(28,100)$ \\
\hline Changes In Inventories & $(27,200)$ & $(52,200)$ & $(50,800)$ \\
\hline Changes In Other Operating Activities & - & - & - \\
\hline Total Cash Flow From Operating Activities & $6,966,100$ & $7,150,100$ & $6,341,600$ \\
\hline \multicolumn{4}{|c|}{ Investing Activities, Cash Flows Provided By or Used In } \\
\hline Capital Expenditures & $(3,049,200)$ & $(2,729,800)$ & $(2,135,500)$ \\
\hline Investments & - & - & - \\
\hline Other Cash flows from Investing Activities & $(118,100)$ & 158,900 & 79,500 \\
\hline Total Cash Flows From Investing Activities & $(3,167,300)$ & $(2,570,900)$ & $(2,056,000)$ \\
\hline \multicolumn{4}{|c|}{ Financing Activities, Cash Flows Provided By or Used In } \\
\hline Dividends Paid & $(2,896,600)$ & $(2,609,700)$ & $(2,408,100)$ \\
\hline Sale Purchase of Stock & $(2,286,500)$ & $(3,029,100)$ & $(2,235,400)$ \\
\hline Net Borrowings & $1,204,600$ & $1,003,900$ & 787,400 \\
\hline Other Cash Flows from Financing Activities & $(13,600)$ & $(10,600)$ & $(1,300)$ \\
\hline Total Cash Flows From Financing Activities & $(3,849,800)$ & $(4,533,000)$ & $(3,728,700)$ \\
\hline Effect Of Exchange Rate Changes & 51,400 & $(97,500)$ & 34,100 \\
\hline Change In Cash and Cash Equivalents & 400 & $(51,300)$ & 591,000 \\
\hline
\end{tabular}


6-Year Summary

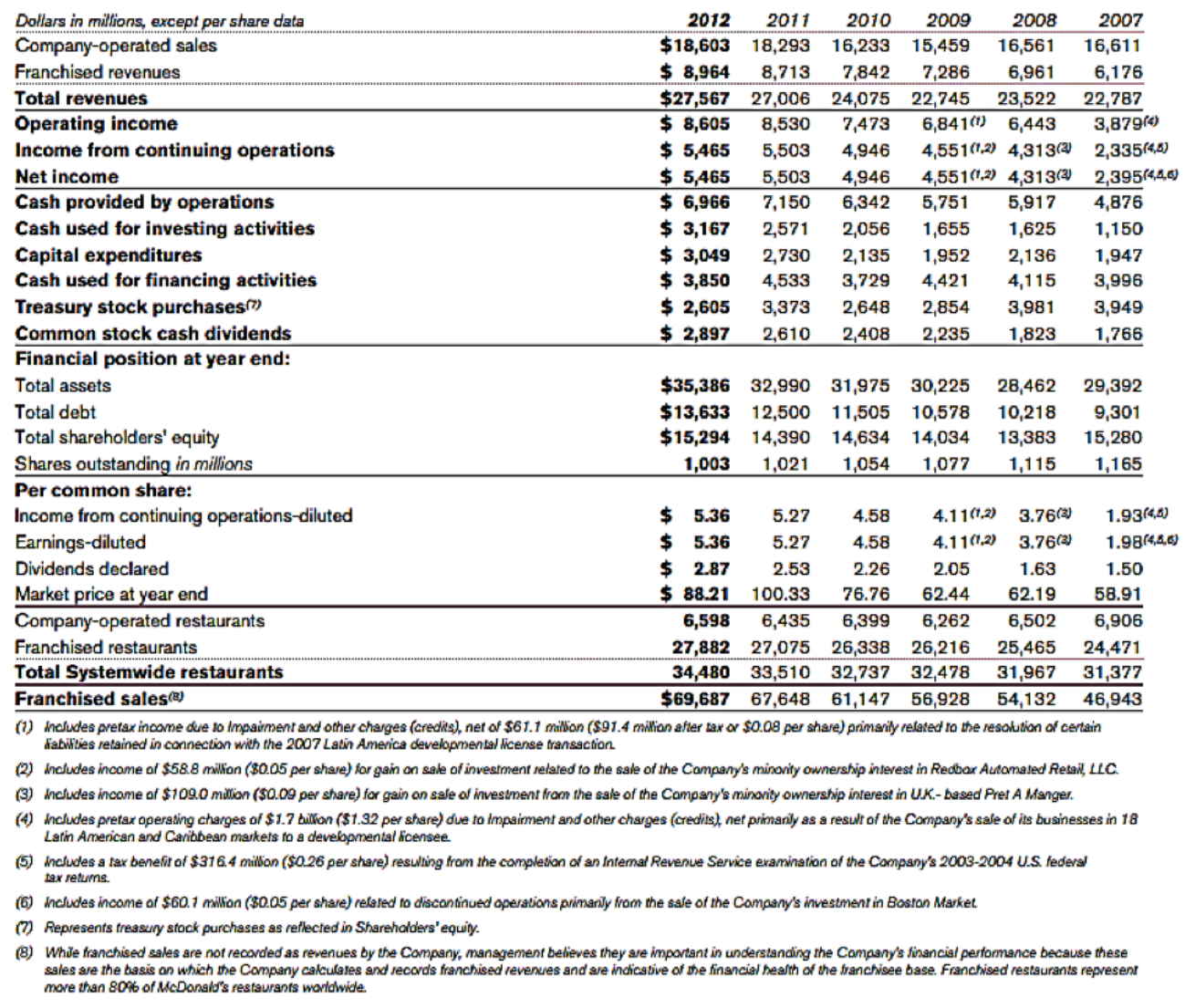


APPENDIX 2 - YUM BRANDS INC.

Income Statement

View: Annual Data | Quarterly Data

Period Ending

Total Revenue

Cost of Revenue

Gross Profit

Operating Expense

Research Development

Selling General and Administrative

Non Recurring

Others

Total Operating Expenses
Get Income Statement for:

GO

All numbers in thousand

Dec 29, 2012 31, 2011 Dec 25, 2010

$13,633,000 \quad 12,626,000 \quad 11,343,000$

\begin{tabular}{lll}
$9,852,000$ & $9,140,000$ & $8,120,000$ \\
\hline $3,781,000$ & $3,486,000$ & $3,223,000$
\end{tabular}

Operating Income or Loss

$\begin{array}{rrr}- & 1,536,000 & 1,407,000\end{array}$

37,000

135,000

47,000

-

Income from Continuing Operations

Total Other Income/Expenses Net
Earnings Before Interest And Taxes

Interest Expense

Income Before Tax

Income Tax Expense

Minority Interest

$1,294,000 \quad 1,815,000 \quad 1,769,000$

Net Income From Continuing Ops

-

Non-recurring Events

Discontinued Operations

Extraordinary Items

Effect Of Accounting Changes

Other Htems

\begin{tabular}{lrrr}
\hline Net Income & $1,597,000$ & $1,319,000$ & $1,158,000$ \\
Preferred Stock And Other Adjustments & - & - & - \\
\hline Net Income Applicable To Common Shares & $1,597,000$ & $1,319,000$ & $1,158,000$
\end{tabular}

\section{Balance Sheet}

Get Balance Sheet for:

View: Annual Data | Quarterly Data

Period Ending

Dec 31, 2011

All numbers in thousands

Assets

Current Assets

Cash And Cash Equivalents

Short Term Investments

Net Receivables

Inventory

Other Current Assets

Total Current Assets

Long Term Investments

Property Plant and Equipment

Goodwill

Intangible Assets

Accumulated Amortization

Other Assets

Deferred Long Term Asset Charges

Total Assets

Liabilities

Current Liabiltties

Accounts Payable

Short/Current Long Term Debt

Other Current Liabilities

Total Current Liabilities

Long Term Debt

Other Liabilities

Deferred Long Term Liability Charges

Minority Interest

Negative Goodwill

Total Liabilities

912,000

412,000

312,000

272,000

$1,909,000$

72,000

$4,250,000$

$1,034,000$

690,000

$2,145,000$

$1,594,000$

$2,145,000$

537,000

$1,597,000$

416,000

$\begin{array}{lr}(16,000) & (20,000) \\ 1,319,000 & 1,158,000\end{array}$

$-$

(2)

Stockholders' Equity

isc Stocks Options Warrants

Redeemable Preferred Stock

Preferred Stock

Common Stock

Retained Earnings

Treasury Stock

Capital Surplus

Other Stockholder Equity

575,000

481,000

$9,011,000$

otal Stockholder Equity

Net Tangible Assets

$2,178,000$

10,000

$2,188,000$

$2,932,000$

$1,579,000$

99,000

$6,798,000$

20000

59,000

000

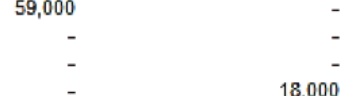

$2,286,000$

18,000

$2,052,000$

$2,130,000$

320,000

273,000

338,000

167,000

$4,042,000$

681,000
299,000

775,000

549,000

25,2010

538,000

317,000

189,000

269,000

$2,313,000$

154,000

$3,830,000$
659,000

475,000

519,000

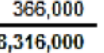

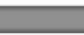

$1,775,000$

\begin{tabular}{rr}
673,000 \\
$-\quad-$ \\
\hline
\end{tabular}

\begin{tabular}{ll}
$2,450,000$ & $\mathbf{4 4 8 , 0 0 0}$ \\
\hline & $2,915,000$
\end{tabular}

$\begin{array}{ll}2,997,000 & 2,915,000 \\ 1,471,000 & 1,284,000\end{array}$

$93,000 \quad 93,000$

$6,011,000 \quad 6,740,000$

$(132,000)$

$2,154,000$

$(247,000)$
$1,823,000$

843,000

$\begin{array}{r}- \\ - \\ - \\ - \\ 86,000 \\ 1,717,000 \\ - \\ - \\ (227,000) \\ \hline 1,576,000 \\ \hline 442,000\end{array}$




\begin{tabular}{|c|c|c|c|}
\hline Cash Flow & & Get Cash Flow for: & GO \\
\hline View: Annual Data | Quarterly Data & \multicolumn{3}{|c|}{ All numbers in thousands } \\
\hline Period Ending & Dec 29, 2012 & Dec 31, 2011 & Dec 25, 2010 \\
\hline Net Income & $1,597,000$ & $1,319,000$ & $1,158,000$ \\
\hline \multicolumn{4}{|c|}{ Operating Activities, Cash Flows Provided By or Used In } \\
\hline Depreciation & 645,000 & 628,000 & 589,000 \\
\hline Adjustments To Net Income & $(176,000)$ & $(8,000)$ & $(82,000)$ \\
\hline Changes In Accounts Receivables & $(18,000)$ & $(39,000)$ & $(12,000)$ \\
\hline Changes In Liabilities & 135,000 & 253,000 & 165,000 \\
\hline Changes In Inventories & 9,000 & $(75,000)$ & $(68,000)$ \\
\hline Changes In Other Operating Activities & 91,000 & 76,000 & 198,000 \\
\hline Total Cash Flow From Operating Activities & $2,294,000$ & $2,170,000$ & $1,968,000$ \\
\hline \multicolumn{4}{|c|}{ Investing Activities, Cash Flows Provided By or Used In } \\
\hline Capital Expenditures & $(1,099,000)$ & $(940,000)$ & $(796,000)$ \\
\hline Investments & - & - & - \\
\hline Other Cash flows from Investing Activities & 94,000 & $(66,000)$ & 217,000 \\
\hline Total Cash Flows From Investing Activities & $(1,005,000)$ & $(1,006,000)$ & $(579,000)$ \\
\hline \multicolumn{4}{|c|}{ Financing Activities, Cash Flows Provided By or Used In } \\
\hline Dividends Paid & $(544,000)$ & $(481,000)$ & $(412,000)$ \\
\hline Sale Purchase of Stock & $(903,000)$ & $(693,000)$ & $(269,000)$ \\
\hline Net Borrowings & $(282,000)$ & $(262,000)$ & 313,000 \\
\hline Other Cash Flows from Financing Activities & $(85,000)$ & $(43,000)$ & $(38,000)$ \\
\hline Total Cash Flows From Financing Activities & $(1,716,000)$ & $(1,413,000)$ & $(337,000)$ \\
\hline Effect Of Exchange Rate Changes & 5,000 & 21,000 & 21,000 \\
\hline Change In Cash and Cash Equivalents & $(422,000)$ & $(228,000)$ & $1,073,000$ \\
\hline
\end{tabular}

YUM! Brands, Inc. and Subsidiaries

(in millions, except per share and unit amounts)

\begin{tabular}{|c|c|c|c|c|c|c|c|c|c|c|}
\hline \multirow[b]{3}{*}{ Summary of Operations } & \multicolumn{10}{|c|}{ Fiscal Year } \\
\hline & \multicolumn{2}{|r|}{2011} & \multicolumn{2}{|r|}{2010} & \multicolumn{2}{|r|}{2009} & \multicolumn{2}{|r|}{2008} & \multicolumn{2}{|r|}{2007} \\
\hline & & & & & & & & & & \\
\hline \multicolumn{11}{|l|}{ Revenues } \\
\hline Company sales & s & 10,893 & $\$$ & 9,783 & s & 9,413 & $\$$ & 9,843 & $\$$ & 9,100 \\
\hline Franchise and license fees and income & & 1,733 & & 1,560 & & 1,423 & & 1,461 & & 1,335 \\
\hline Total & & 12,626 & & 11,343 & & 10,836 & & 11,304 & & 10,435 \\
\hline Closures and impairment income (expenses) ${ }^{(t)}$ & & $(135)$ & & $(47)$ & & (103) & & (43) & & (35) \\
\hline Refranchising gain (loss) ${ }^{(a)}$ & & (72) & & (63) & & 26 & & 5 & & 11 \\
\hline Operating Profit ${ }^{(b)}$ & & 1,815 & & 1,769 & & 1,590 & & 1,517 & & 1,357 \\
\hline Interest expense, net & & 156 & & 175 & & 194 & & 226 & & 166 \\
\hline Income before income taxes & & 1,659 & & 1,594 & & 1,396 & & 1,291 & & 1,191 \\
\hline Net Income - including noncontrolling interest & & 1,335 & & 1,178 & & 1,083 & & 972 & & 909 \\
\hline Net Income-YUM! Brands, Inc. & & 1,319 & & 1,158 & & 1,071 & & 964 & & 909 \\
\hline Basic eamings per common share & & 2.81 & & 2.44 & & 2.28 & & 2.03 & & 1.74 \\
\hline Diluted earnings per common share & & 2.74 & & 2.38 & & 2.22 & & 1.96 & & 1.68 \\
\hline Diluted earnings per common share before Special Items ${ }^{(k)}$ & & 2.87 & & 2.53 & & 2.17 & & 1.91 & & 1.68 \\
\hline \multicolumn{11}{|l|}{ Cash Flow Data } \\
\hline Provided by operating activities & s & 2,170 & $\$$ & 1,968 & \$ & 1,404 & $\$$ & 1,521 & $\$$ & 1,551 \\
\hline Capital spending, excluding acquisitions and investments & & 940 & & 796 & & 797 & & 935 & & 726 \\
\hline Proceeds from refranchising of restaurants & & 246 & & 265 & & 194 & & 266 & & 117 \\
\hline Repurchase shares of Common Stock & & 752 & & 371 & & - & & 1,628 & & 1,410 \\
\hline Dividends paid on Common Stock & & 481 & & 412 & & 362 & & 322 & & 273 \\
\hline \multicolumn{11}{|l|}{ Balance Sheet } \\
\hline Total assets & s & 8,834 & $\$$ & 8,316 & \$ & 7,148 & $\$$ & 6,527 & $\$$ & 7,188 \\
\hline Long-term debt & & 2,997 & & 2,915 & & 3,207 & & 3,564 & & 2,924 \\
\hline Total debt & & 3,317 & & 3,588 & & 3,266 & & 3,589 & & 3,212 \\
\hline \multirow{2}{*}{\multicolumn{11}{|c|}{$\begin{array}{l}\text { Other Data } \\
\text { Number of stores at year end }\end{array}$}} \\
\hline & & & & & & & & & & \\
\hline Company & & 7,437 & & 7,271 & & 7,666 & & 7,568 & & 7,625 \\
\hline Unconsolidated Affiliates & & 587 & & 525 & & 469 & & 645 & & 1,314 \\
\hline Franchisees $^{(d)}$ & & 26,928 & & 27,852 & & 26,745 & & 25,911 & & 24,297 \\
\hline Licensees & & 2,169 & & 2,187 & & 2,200 & & 2,168 & & 2,109 \\
\hline System ${ }^{(4)}$ & & 37,121 & & 37,835 & & 37,080 & & 36,292 & & 35,345 \\
\hline \multicolumn{11}{|l|}{ China Division system sales growth ${ }^{(c)}$} \\
\hline $\begin{array}{l}\text { Reported } \\
\text { Local currency }{ }^{(n)}\end{array}$ & & $\begin{array}{l}35 \% \\
29 \%\end{array}$ & & $\begin{array}{l}18 \% \\
17 \%\end{array}$ & & $\begin{array}{l}11 \\
10\end{array}$ & & $\begin{array}{l}33 \% \\
22 \%\end{array}$ & & $\begin{array}{l}34 \% \\
28 \%\end{array}$ \\
\hline \multicolumn{11}{|l|}{ YRI system sales growth ${ }^{(e)}$} \\
\hline Reported & & $13 \%$ & & $10 \%$ & & (4) & & $10 \%$ & & $15 \%$ \\
\hline Local currency ${ }^{(n)}$ & & $8 \%$ & & $4 \%$ & & 5 & & $8 \%$ & & $10 \%$ \\
\hline U.S. same store sales growth ${ }^{(t)}$ & & $(1) \%$ & & $1 \%$ & & (5) & & $2 \%$ & & $-\%$ \\
\hline Shares outstanding at year end & & 460 & & 469 & & 469 & & 459 & & 499 \\
\hline Cash dividends declared per Common Stock & s & 1.07 & $\$$ & 0.92 & \$ & 0.80 & $\$$ & 0.72 & $\$$ & 0.45 \\
\hline Market price per share at year end & 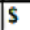 & 59.01 & $\$$ & 49.66 & $\$$ & 35.38 & $\$$ & 30.28 & $\$$ & 38.54 \\
\hline
\end{tabular}

